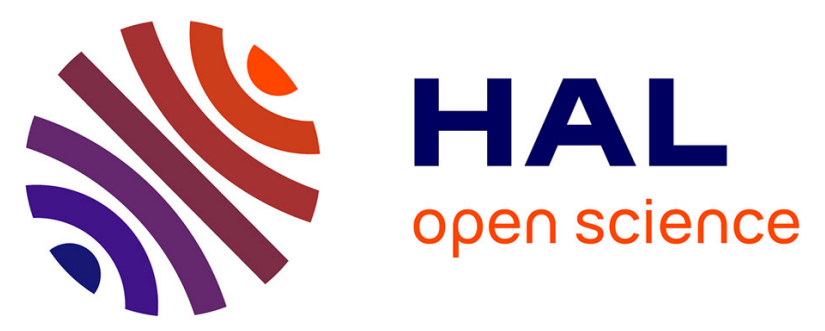

\title{
Slope-to-basin stratigraphic evolution of the carbonate northwestern Great Bahama Bank (Bahamas) during the Neogene to Quaternary: interactions between downslope and bottom currents deposits
}

Melanie Principaud, Jean-Pierre Ponte, Thierry Mulder, Hervé Gillet, Cécile Robin, Jean Borgomano

\section{To cite this version:}

Melanie Principaud, Jean-Pierre Ponte, Thierry Mulder, Hervé Gillet, Cécile Robin, et al.. Slope-tobasin stratigraphic evolution of the carbonate northwestern Great Bahama Bank (Bahamas) during the Neogene to Quaternary: interactions between downslope and bottom currents deposits. Basin Research, 2017, 29 (6), pp.699-724. 10.1111/bre.12195 . insu-01294294

\section{HAL Id: insu-01294294 \\ https://hal-insu.archives-ouvertes.fr/insu-01294294}

Submitted on 29 Mar 2016

HAL is a multi-disciplinary open access archive for the deposit and dissemination of scientific research documents, whether they are published or not. The documents may come from teaching and research institutions in France or abroad, or from public or private research centers.
L'archive ouverte pluridisciplinaire HAL, est destinée au dépôt et à la diffusion de documents scientifiques de niveau recherche, publiés ou non, émanant des établissements d'enseignement et de recherche français ou étrangers, des laboratoires publics ou privés. 
Received Date : 22-May-2015

Revised Date : 10-Mar-2016

Accepted Date : 18-Mar-2016

Article type : Original Article

Slope-to-basin stratigraphic evolution of the carbonate northwestern Great Bahama Bank (Bahamas) during the Neogene to Quaternary: interactions between downslope and bottom currents deposits

Principaud, Mélanie*, Ponte, Jean-Pierre**, Mulder, Thierry*, Gillet, Hervé*, Robin, Cécile**, Borgomano, Jean***

* Université de Bordeaux, UMR 5805 EPOC, Bat B18, Allée Geoffroy St Hilaire, 33615 Pessac cedex, France

** Université de Rennes 1, UMR 6118, Campus de Beaulieu, 35042 Rennes Cedex, France *** Total Centre Scientifique et Technique Jean Féger, 64018 Pau cedex, France

*Corresponding author: melanie.principaud@u-bordeaux.fr

\section{Keywords}

Seismic stratigraphy

Carbonates

Contourite drift

Mass-flow deposits

Great Bahama Bank

Neogene-Quaternary

This article has been accepted for publication and undergone full peer review but has not been through the copyediting, typesetting, pagination and proofreading process, which may lead to differences between this version and the Version of Record. Please cite this article as doi: $10.1111 /$ bre. 12195

This article is protected by copyright. All rights reserved. 


\section{ABSTRACT}

Multichannel high-resolution seismic data along the northwestern margin of the Great Bahama Bank (GBB), Bahamas, details the internal geometry and depositional history of a Neogene-Quaternary carbonate slope-to-basin area.

The stratigraphic architecture through this period evolves from (i) a mud-dominated slopeapron during the Miocene, (ii) a debris-dominated base-of-slope apron during the Late Pliocene, and then (iii) return to a slope-apron with very short prograding clinoformal aprons during the Pleistocene. This geometric evolution was broadly constrained by the development of the Santaren Drift by bottom current since the Langhian. The drift expands along the northwestern GBB slope, forming a continuous correlative massive feature that shows successive phases of growth and retreat and influenced the downslope sediments distribution. Indeed, Late Pliocene deposits are confined into the moat, forming a strike-continuous coarse debrites belt along the mid-slope, preventing their free expansion into the basin. The occurrence of basinal drift that operated since 15 Ma showed a significant upslope growth around 3.6 $\mathrm{Ma}$ and is interpreted as resulting from the closure of the Central American Seaway (CAS) which also coincides with a global oceanographic re-organization and climate changes in the Northern Hemisphere.

\section{INTRODUCTION}

The Great Bahama Bank (GBB) is the largest shallow-water platform of the Bahamian archipelago, which forms an extensive carbonate province in the southeastern part of North America (Fig. 1). It is the best modern example of an isolated platform operating under tropical conditions, and has been a highly productive carbonate factory since its inception in the Upper Jurassic (Masaferro \& Eberli, 1999). The western side of the GBB currently consists of a leeward open margin, which has prograded about $27 \mathrm{~km}$ towards the Florida Straits since the Late Cretaceous (Eberli \& Ginsburg, 1987, 1989). It is characterized by a slope averaging 2-8 ${ }^{\circ}$ from 250-800 m water depth (Jo, 2013; Betzler et al., 2014).

The GBB was mainly aggradational during the Lower Neogene, and was characterized by the vertical stacking of the shelf edge associated with a gently dipping slope. From the Middle Miocene, the platform has developed a more prograding pattern, with a steep end-member slope and massive sedimentary apron (Eberli \& Ginsburg, 1987, 1989). In contrast, the Late Pliocene and Quaternary show a significant turnover from a distally steepened ramp to a flattopped platform (Eberli \& Ginsburg, 1987, 1989). 
Carbonate production on the GBB platform is interpreted as having been largely controlled by sea-level fluctuations (Eberli et al., 1997b; Betzler et al., 1999). The easterly prevailing wind regime (Wilson \& Roberts, 1992, 1995) in the Bahamian region strongly influences the dominant east-west direction of the progradation and is therefore thought to be the result of preferential off-bank sediment transport on the western leeward margin (Hine \& Neumann, 1977; Hine et al., 1981b) and responsible for resedimented deposits upon the slope and in the basin (Wilber et al., 1990; Rendle \& Reijmer, 2002). The highest sedimentation rates are commonly assigned to late stage of sea-level highstands, prior to platform flooding (Schlager, 1981; Mullins, 1983), whilst the falling stages exposed the platform and restricted the sediment production to the fringes. However, Reijmer et al. (2012) demonstrated that, although the platform-slope-derived sedimentation can be consider as reduced, skeletaldominated calciturbidite can be largely exported during high-frequency glacial sea-level lowstands.

The growth of the platform was controlled both by major sea level changes (Eberli \& Ginsburg, 1989) and by the Miocene-Pliocene tectonic activity linked to the closure of the CAS (Duque-Caro, 1990; Steph et al., 2006) that caused a global ocean re-organization and climate changes (Mullins et al. 1987; Haug \& Tiedemann, 1998; Bartoli et al., 2005; Potter \& Szatmari, 2009). These global changes therefore affected the platform ecosystems (appearance of Acropora palmata, McNeill et al., 1997) and associated carbonate productivity.

Although a large number of seismic data sets, coring expeditions and Ocean Drilling Program (ODP) in the Bahamas area have revealed the general anatomy of the slopes and basins as well as documented platform progradation, facies, and sedimentation processes (Mullins \& Neumann, 1979; Schlager \& Chermak, 1979; Crevello \& Schlager, 1980; Sheridan et al., 1981; Mullins et al., 1984; Austin et al., 1986; Ladd \& Sheridan, 1987; Schlager et al., 1988; Eberli et al., 1997a; Ginsburg, 2001; Bergman, 2005), a detailed analysis of the platform-slope-basin system at a regional scale has not been undertaken. New high-quality multibeam and seismic data imaging the northwestern slope of the GBB and the adjacent floor of the Florida Straits (Mulder et al., 2012) allow us to better constrain deepwater processes and to reconstruct the margin and basin architecture evolution during the Neogene-Quaternary.

The purpose of this paper is to characterize the depositional sequences, their geometry and associated facies along the northwestern GBB slope. Seismic reflection data and core descriptions enable us to propose a conceptual depositional model for the Neogene- 
Quaternary carbonates. Furthermore, control factors are discussed that: (i) explain the slope apron morphologic variability along strike during the Miocene period, (ii) evaluate the role of large-collapse deposits upon the slope apron physiography, (iii) highlight the influence of the bottom currents and associated contourite deposits upon the downslope deposits and their along strike distribution.

\section{GEOLOGICAL SETTING}

Geodynamic evolution of the Bahamas and major structural events

The present-day configuration of the Bahamian archipelago results in a complex geodynamic evolution of the Caribbean realm that was punctuated by a succession of structural episodes since the opening of the North Atlantic during the Late Jurassic - Early Cretaceous (Pindell, 1985; Denny III et al., 1994). Late Jurassic rifting was followed by the development of a widespread marine carbonate mega-platform ("megabank") during the Lower Cretaceous that extended over an extensive geographic area including the Bahamas (Ladd \& Sheridan, 1987). Shallow marine limestones interbedded with evaporites predominantly occur over the western Bahamas due to significant thermal subsidence and an important drowning known in the Middle Cretaceous (Schlager et al., 1988).

The Late Cretaceous was a time of tectonic plate re-arrangement affecting the Caribbean region (Pindell, 1985; Ross \& Scotese, 1988; Pindell \& Kennan, 2001). The megabank was subsequently fragmented by a series of prevalent N-S oriented fault-bounded horsts and deep grabens (Sheridan et al., 1981; Corso et al., 1985). The northwestern Great Bahama Bank was segmented into two smaller shallow carbonates banks (Bimini and Andros) separated by a fault-bounded N-S-trending corridor (i.e. Straits of Andros) (Eberli \& Ginsburg, 1987). Further south, faults were reactivated as normal faults to create several deep, narrow, WNWstriking troughs separating isolated carbonate banks (Masaferro \& Eberli, 1999). The Santaren Channel was also segmented by NW-striking normal faults with offsets up to 1200 m (Masaferro \& Eberli, 1995). Faulting-related topography still locally prevails at the seafloor along the GBB (Sheridan et al., 1981; Bergman, 2005).

The Late Cretaceous - Middle Eocene was marked by the Cuban Orogeny, which was caused by collision between the Caribbean and North American plates. The northern margin of Cuba formed a thrusting arc belt advancing northward over the southern Bahamas. The collision caused re-organization of the West Bahamian realm, which was locally affected by the re- 
activation of Jurassic faults, the formation of NW-SE thrust and folds, WNW striking strikeslip faults and the establishment of a flexural forebulge in the newly formed South GBB foreland (Masaferro, 1997; Masaferro \& Eberli, 1999). Masaferro (1997) suggests that uplift due to the forebulge migration away from the collision zone, may have initiated exposure of the Cretaceous carbonate banks in the south GBB and possible further north. This hypothesis is confirmed by Bergman (2005) who demonstrates that such a northward far-field deformation migration progressively operated through time along the GBB, forming compressional folds, thrusts and syntectonic unconformities at the top of the inherited buried blocks. The south of the Santaren Channel was affected by the Cuban Orogeny in the Late Cretaceous whilst the north of the GBB displayed Cuban contractional deformation and erosion during the Late Oligocene ( $25 \mathrm{Ma})$. Submarine growth of the Santaren Anticline with coeval syn-tectonic sedimentation both indicate that contraction remained active during the entire Neogene in the south of the Santaren Channel but was marked by episodic higher rates of uplift and folding (Masaferro \& Eberli, 1999; Masaferro et al., 2002).

The fragmented Cretaceous GBB carbonate shelves coalesced during the Neogene due to the subsequent aggradation and progradation of an extensive carbonate platform that prograded over $27 \mathrm{~km}$ towards the west from the Bimini Bank (Eberli \& Ginsburg, 1987, 1988, 1989). Due to its inherited segmentation, the western shelf-edge displayed an asymmetrical configuration during the Tertiary and is characterized by a gentle N-S oriented curvature in the southern part whilst, in the north, the Bimini Bank shows a net protrusion towards the west (Hine \& Neumann, 1977; Hine et al., 1981b; Eberli \& Ginsburg, 1987, 1989). Since its inception during the Late Oligocene, the Bimini Embayment formed a morphological reentrant that would play a crucial role in the configuration of the GBB and the distribution of sediments during the all Neogene.

\section{Currents}

The western slope of GBB is currently dominated by both shallow- and deep-water currents that flow in the Florida Straits and the Santaren Channel (Fig. 1). The Florida Current is a strong surface-water current that flows northward (Mullins et al., 1987; Leaman et al., 1995; Lee et al., 1995; Wang \& Mooers, 1997, 1998). It is mainly nourished by the outflow of the Loop Current of the Gulf of Mexico, with contributions of inflow from a weaker shallow current through the Santaren Channel (Atkinson et al., 1995; Leaman et al., 1995). Both main shallow currents influence bottom deposits and give rise to several contourite drifts in the 
study area (Fig.1) (Hine et al., 1981a; Bergman, 2005). At greater water depth, minor countercurrents and tidally-driven reversing currents form in Florida (Grasmueck et al., 2006; Correa et al., 2012).

Bottom currents are important in the slope- to- basin transition because they can winnow and rework slope deposits, or prevent accumulation entirely, resulting in periods of no net accumulation (Coniglio \& Dix, 1992).

\section{DATA AND METHODS}

This study relies on a $\sim 1480 \mathrm{~km}$ grid of 2D High-Resolution multichannel seismic reflection data covering approximately $5000 \mathrm{~km}^{2}$, collected on the R/V Le Suroit during Leg 1 of the Carambar cruise in November 2010 (Mulder et al., 2012) (Fig. 1). The seismic lines have an average spacing of $2.5 \mathrm{~km}$ for dip sections and between 5 and $30 \mathrm{~km}$ for margin-parallel sections. Seismic sections were shot using a mini-GI 24/24 in ${ }^{3}$ air gun, and a 96-traces /700m-long streamer with an average acoustic frequency signal of 40-350 Hz. Streamer and source positioning were derived from vessel DGPS. Processing of this seismic data was performed using SISPEED software (CIfremer). Basic processing flow included (1) NMO correction, (2) 96 fold stacking and (3) constant velocity gradient migration. The obtained data are of excellent quality, with vertical resolution approaching $2 \mathrm{~m}$ and usable acoustic imaging to approximately $\sim 1 \mathrm{~s}$ of two-way travel time (TWTT).

The 2D seismic survey is intersected by six published wells that were drilled along the slope, the base of slope and the adjacent basin of the Great Bahama Bank during two successive Ocean Drilling Program (ODP) legs 101 and 166, (respectively held in 1985 and 1996) (Austin et al., 1986; Eberli et al., 1997a). Five wells were drilled in the southern part of the study area (wells 1005, 1004, 1003, 1007 and 1006) whereas only one was performed in the northern part (well 626). Two other exploration wells (Clino and Unda) were drilled on the top of the platform as part of the Bahamas Drilling Project (Ginsburg, 2001), along a seismic line originally acquired by Western Geophysical (henceforth known as the Western Line; Eberli \& Ginsburg, 1987). These latter two wells represent the shallow-water sites and complete the transect from the platform to the basin (Figs. 2 and 3). The re-examination of the Great Isaac well on northwestern GBB (Fig. 2) by Schlager et al. (1988) allowed retracing of its sedimentary succession and depositional settings evolution since the midCretaceous. 
Well tying, seismic calibration and chronostratigraphic framework

Time-depth conversion and subsequent seismic interpretation were performed using the Sismage software package (CTotal). The seismic profile that crosses ODP wells 1003, 1004, 1006 and 1007 is used for time-depth conversion and to tie well data to seismic data. For each well, measurements of physical properties (P-wave velocity, density and natural gamma-ray) are imported and a check-shot survey was used to define a time-depth law for each one (Fig. 4). Calibration between well and seismic data and the time-depth law returned by Sismage software is illustrate in Figure 4 by the well 1007.

Ages of the seismic reflectors are provided from accurate chronological constraints based on planktonic foraminifer and nannofossil zones from the Late Oligocene to the Pleistocene, which facilitate regional correlations performed using the ODP wells (Eberli et al., 1997a). Absolute ages were updated with the Time Scale from Cohen et al. (2013).

\section{Seismic interpretation}

SISMAGE software (CTotal) was used for interpretation of the processed seismic sections. The Neogene to present day stratigraphic succession encountered within the 2D survey has been subdivided into nine seismically correlative depositional units, bounded by laterally extensive and regionally key stratigraphical surfaces defined as sequence boundaries (SB) according to Mitchum et al. (1977), Vail et al. (1977) and Sarg (1988) terminology. The SB have been define from platform to basin and calibrated in time with planktonic foraminifera and nannofossil biozones (Eberli et al., 1997; Eberli, 2000).

The surfaces are named from their relative age, from the Late Oligocene Surface (L. Olig) through to Pleistocene Surface (Ple.4) (Table 1), and the depositional packages are numbered from the chronologically oldest to the youngest: Seismic Unit 1 (SU-1) to Seismic Unit 9 (SU-9). The nine depositional packages and their bounding surfaces are analyzed in this paper. The ODP wells have been correlated with respect of bio-zonations, facies sequences issued from cores studies and geometries interpreted from seismic sections (Fig. 5). Both isochron and isochore maps (in milliseconds of two-way travel time and approximate thickness in meters), respectively attributed to each bounding surfaces and seismic sequences, are illustrated in Figs 11 and 12. Seismic facies were identified and grouped according to their interpreted depositional system. They were distinguished through a series of properties such as reflection configuration, amplitude, geometry and structure, lateral facies 
relationships, geometries of the bounding surfaces, lithology and depositional environment. The six ODP wells (Legs 101 and 166) within the study area provide the lithology calibration of the seismic data (Table 2).

\section{RESULTS}

\section{Seismic stratigraphy of the northwestern slope of the Great Bahama Bank}

SU-1: Late Oligocene ( 25 Ma) - Burdigalian (19.8 Ma)

SU-1 is to the oldest unit described in this study and consists of an aggrading succession. It is bounded at the base by the conformable Late Oligocene surface (L.Olig) that usually appears as a distinct high-amplitude, semi-continuous seismic reflector (Figs. 6-8). The surface is poorly dated owing to a lack of chronological data. Because of similarities between seismic attributes (reflectivity, discontinuity, morphology), however, it may be correlated with the $\mathrm{Br}$ surface of Ladd \& Sheridan (1987) and the L. Olig horizon of Bergman (2005), and therefore is assigned to Late Oligocene ( $25 \mathrm{Ma}$ ). The top of SU-1 is limited by the Burdigalian surface Bur (19.4 Ma) (Figs. 6-8), which consists of a low- to medium-amplitude, semicontinuous, conformable seismic reflector. Strata are planar and horizontal in the south, whilst they are affected by gentle NE-SW oriented domal structures in the northern basin.

SU-1 consists of as a set of very low-amplitude and semi-continuous seismic reflectors, which conformably overlay the L.Olig Surface. In the southern area, strata onlap towards the east against the escarpment surface inherited from the southern faulted Bimini Bank (Fig. 3) (Eberli \& Ginsburg, 1987, 1988, 1989). Here, SU-1 therefore forms a west-dipping aggrading slope apron disconnected from the easterly Late Cretaceous - Early Tertiary escarpment margin.

In the southern area, facies of the uppermost part of SU-1 are made up of mud-supported biowackestones with intercalated cherts (wells 1007 and 1003) (Eberli et al., 1997a), whereas in the northern area, well 626 shows grain-supported facies characterized by skeletal packstones to grainstones with cherts (Austin et al., 1986). Even further north, the Great Isaac well indicates neritic packstones to grainstones with minor pelagic muds, interpreted as deepwater slope deposits (Schlager et al., 1988).

\section{SU-2: Burdigalian (19.8 Ma) - Langhian (15.9 Ma)}

The SU-2 seismic unit is bounded at the base by the Bur surface, which is a downlap surface in the northern area (Figs. 5 and 7) but is rather horizontal and conformable in the south (Figs. 7 and 8). The top of SU-2 is limited by the Langhian surface Langh (15.9 Ma), which 
is mostly characterized by an irregular and unconformable seismic reflector over the whole study area. In the north, the surface plunges rapidly westward and is affected by amalgamated V-shaped incised valleys (Fig. 6).

SU-2 forms a massive slightly tilted progradational wedge in the northern part of the study area (thickness $>300 \mathrm{~ms}$ ) that progressively thins $(\sim 75 \mathrm{~ms})$ towards the $\mathrm{SW}$ downlapping the Bur Surface over $25 \mathrm{~km}$ (Fig. 6). Here, the unit is made up of sub-parallel, semi-continuous, hummocky clinoforms, characterized by medium- to high-amplitude, sometimes forming amalgamated convex lenses that orientate perpendicularly to the slope. Well 626 indicates skeletal-foraminiferal packstone facies rich in skeletal packstone and grainstone clasts, interbedded with cherts and limestones at the base of the unit (Austin et al., 1986). Laterally, stacked chaotic facies associated with erosional sub-vertical scars are interpreted as MTCs accumulated at the base-of-slope of the SW flank of the northern Bimini Bank (Fig. 8).

SU-2 thins downslope where it progressively passes to continuous and conformable, mediumto high-amplitude undulated reflectors (SF-1, Table 2). These basinal facies show a relatively constant thickness ( 80-100 ms) over the southern area and are interpreted as hemipelagic deposits. In the south, similarly as for the previously described SU-1, SU-2 pinches out towards the east against a faulted escarpment surface of the Bimini block of the ancient easterly platform (Fig. 3) (Eberli \& Ginsburg, 1987, 1988, 1989). Wells 1007 and 1003 indicate mud-supported bio-wackestones with dark-grey inter-beds of bioclastic packstones to floatstones that grade westward into SF-1, which is interpreted as hemipelagic ooze.

\section{SU-3: Langhian (15.9 Ma) - Serravallian (11.9 Ma)}

SU-3 is bounded at the base by the Langh surface and at the top by the conformable Upper Serravallian surface Se.2 (11.9 Ma). Se. 2 displays a sub-horizontal and continuous seismic reflector in the south and west (Figs. 6 and 7) whilst it becomes irregular and unconformable in the north (Fig. 6). In the south, SU-3 corresponds to an aggradational to progradational wedge ( $\sim 500 \mathrm{~ms}$ thick) that progressively thins ( $75 \mathrm{~ms})$ westwards (Fig. 3). It mainly displays semi-continuous low-angle prograding clinoforms with dips between $2.7^{\circ}$ and $0.3^{\circ}$ according to Betzler et al. (1999) and characterized by medium- to high-amplitude reflectors. Stacked convex lenses (SF-3, Table 2) are observed along strike (Fig. 8). Wells 1007 and 1003 (Fig. 4) indicate that SF-3 is composed of mud-rich carbonates made up of an alternation of light-grey wackestones/packstones dominated by shallow-water allochems and planktonic foraminifera and dark-grey wackestones/packstones rich in clay minerals (>15\%). These deposits are interbedded with packstones to floatstones rich in shallow-water bioclasts 
and planktonic foraminifera (Eberli et al., 1997a; Betzler et al., 1999; Betzler et al., 2000). On the northern margin, the unit thins upslope (35 ms) but still conformably overlays the SU2 unit (Fig. 8).

The toe-of-slope and the basin are characterized by smooth, parallel and continuous reflections of medium-amplitude (SF-2, Table 2). In the south, this facies interfingers with SF-3 (Figs. 3 and 5) whilst in the north area, it onlaps the Langh surface (Fig. 6). Strata wedge out towards the south-west and form a thick mound-shaped body at the base-of-slope that migrates upslope towards the north (Fig. 6). Austin et al. (1986) described winnowed skeletal sands with planctonic foraminifera in well 626.

In the northern area, SF-2 is occasionally cross-cut along the slope by a series of sharpbounded 100-200 ms thick (TWT) coffer-like strata made up of low- to medium-amplitude chaotic facies in which remnant stratified packages have also been observed (SF-7). These facies form large stacked collapse blocks that have glided downslope upon a series of decollement surfaces within SU-2/3. They are interpreted as MTCs that extend over $25 \mathrm{~km}$ in the basin, up to $70 \mathrm{~km}$ along-strike (Fig. 8). The vertical scars are localized in the upper to middle slope, which is made up of the previously formed apron of SU-3. MTCs extend basinwards over more than $20 \mathrm{~km}$.

SF-7 passes laterally into a chaotic to moderately discontinuous layered facies (SF-6, Table 2), which locally displays a concave lens shape with an erosive basal surface. At well 626, SF-6 is made up of around $50 \mathrm{~m}$ of coarse-grained bio-packstones, floatstones to rudstones that are rich in lithified skeletal lithoclasts of oyster shells and coral fragments. It is interpreted as mud- to grain-supported debrites overlain by high-density turbidites (Austin et al., 1986). SF-7 may pass downslope into SF-6, suggesting that upslope rock-fall mechanisms may trigger downslope erosive debris-flows processes through a unique and localized gravity-flow carbonate event.

\section{SU-4: Serravallian (11.9 Ma) - Messinian (5.7 Ma)}

SU-4 is bounded at the base by the Se.2 surface and at the top by the Messinian surface Me assigned to the top of the Messinian sub-stage (5.7 Ma) (Figs. 6 and 7), which corresponds with a sub-horizontal and conformable reflector in the basin but becomes strongly unconformable, displaying irregular features incised by deep (30-50 ms) V-shaped valleys in the upper slope (Fig. 6) (Anselmetti et al., 2000). 
To the south, the unit is a thick progradational wedge ( $250 \mathrm{~ms})$ that progressively thins to the west $(\sim 120 \mathrm{~ms})$ and terminates over $25 \mathrm{~km}$ from the slope edge (Figs. 3 and 5). The wedge displays semi-continuous, sub-parallel low-angle (between $1.2^{\circ}$ and $3.3^{\circ}$ ) clinoforms that downlap the Ser.2 surface (Figs. 7 and 8) (Betzler et al., 1999). Clinoforms consist of medium- to high-amplitude hummocky to wavy reflectors that may coalesce to form amalgamated convex lenses (SF-3, Table 2). Wells 1007 and 1003 reveal an alternation of wackestones/packstones dominated by shallow-water allochems and planktonic foramifera. Inter-beds of mud-supported bio-packstones to floatstones rich in planktonic foraminifera also occur on the mid and upper slopes.

In the northeast, west-dipping sigmoidal clinoforms form a perched prism that lies at the upper slope and spreads out over less than $10 \mathrm{~km}$ downslope. Numerous lithified slightly tilted $4 \mathrm{~km}$-long mega-blocks are still attached at the upper slope and illustrate the instability of SU-4 (Figs. 7 and 9). Here, SU-4 locally backfills the depression produced by the scar of the Mass Transport Complexes triggered during SU-3 (Fig. 9). This stranded SU-4 rapidly thins towards the west until it reaches the basinal setting, where it passes laterally into horizontal reflectors (SF-1) (Figs. 7 and 9).

Basinal seismic facies are characterized by conformable and continuous reflectors of medium-amplitude (SF-2, Table 2). They are represented by muddy facies in wells 626 and 1006 and have been interpreted as drift deposits (Austin et al., 1986; Eberli et al., 1997a). In the south, contourites commonly interfinger with the downslope facies of the adjacent apron as they progressively grade upslope towards the east (Figs. 3 and 5). Here, the upbuilding of the accreting Miocene slope apron tended to progressively slows down at the expense of the eastward encroachment of the contourite deposits. In the north, although drift deposits are observed in well 626 (Austin et al., 1986), this upslope migration is less obvious as deposits pass laterally to lower foreslope facies (Fig. 6).

\section{SU-5: Messinian (5.7 Ma)- Early Pliocene (3.6 Ma)}

The SU-5 seismic unit is bounded at the base by the erosional Me surface and at the top by the Early Pliocene surface Pl.1 (3.6 Ma) that distinctively occurs as a high-amplitude, continuous seismic reflectors over the study area (Figs. 6-8). The Pl.1 surface is planar and horizontal in the basin (Fig. 7) whilst it erosional along the slope, where it is characterized by V-shaped incised valleys (Figs. 3, 5 and 10). It disappears in the east and north (Figs. 8 and 9). 
On the southern slope, SU-5 is a thin $(25-50 \mathrm{~ms})$ interval of continuous and conformable reflections of very low amplitude (SF-1) which interfinger with SF-2 at the toe-of-slope (Table 2 and Figs. 3 and 5). This interval consists of hemipelagic chalk rich in nannofossils in wells 1005, 1003 and 1007, and entirely fills the incised valleys and gullies of the previous Me surface in the upper slope. In well 626, SU-5 is a coarse-grained condensed section about $25 \mathrm{~m}$ thick, in which a volcanic ash layer has been recorded (Austin et al., 1986). In the basin, a 130 m thick wedge of tabular high-amplitude facies (SF-2, Table 2) thins out toward the slope and is interpreted as being contourites.

\section{SU-6: Early Pliocene (3.6 Ma) - Late Pliocene (2.6 Ma)}

SU-6 is bounded at the base by the Pl.1 surface, which is defined by a continuous, highamplitude reflector and forms a major onlap-to-downlap surface over the entire area. The unit is topped by the Late Pliocene surface Pl.2. (2.6 Ma), which is an irregular, unconformable surface along the slope (Figs. 7-8) and which becomes conformable and continuous in the basin (Fig. 6). Pl.2 locally merges with Pl.1 at the middle slope position in the south (Figs. 3 and 5).

SU-6 is a $200 \mathrm{~m}$ thick mounded stratified morphologic feature of sub-parallel, low-amplitude reflections (Fig. 8) (SF-2, Table 2), that thickens in the basin and progrades upslope towards the easterly slope. Well 1006 shows very fine-grained stratified calcite ooze/chalk with silts and clays that are rich in nannofossils and planktonic foraminifera (Eberli et al., 1997a). SU6 can be subdivided into two sub-units. The lower sub-unit shows a smooth mounded geometry with a progradational configuration both northward and eastward (Figs. 5 and 8). Downlap terminations on $\mathrm{Pl}-1$ surface define an asymmetric shape with a steeper northern and eastern slope bounded by a well-developed moat (Figs. 7 and 9). Conformable stacked seismic horizons dominate in the basin. The upper sub-unit has a sigmoidal to oblique mound geometry, with a marked aggradational component that laterally changes into a steeper eastdipping progradational geometry also characterized by eastward downlap terminations upon $\mathrm{Pl-1}$. Although this sub-unit shows high-amplitude reflectors, seismic facies (SF-2) are similar to the underlying sub-unit (Eberli et al., 1997a). The upper sub-unit shows an important upslope migration characterized by 1's to 10's km rapid translation ( $<1 \mathrm{~m}$.y.).

SU-6 is interpreted as massive mounded contourite drift, according to the classification of Faugères et al. (1999) and Bergman (2005). This drift formed during two distinct building phases. In the median part of the study area, SU-6 is cross-cut by a series of vertically sharpbounded 1-2 km wide chaotic facies (SF-7, Table 2) that extend over 10 to $20 \mathrm{~km}$ in the 
basin. These facies have been interpreted as large-collapse that occurred during the Pliocene and formed MTCs interbedded into contourites (Principaud et al., 2015). In the south muddominated peloidal limestones coevally occur along the upper slope, suggesting a concomitant stranded slope apron deposition upslope (wells 1004 and 1005) (Eberli et al., 1997a) (Fig. 5).

\section{SU-7 : Late Pliocene (2.6 Ma)-Pleistocene (1.7 Ma)}

SU-7 is bounded at the base by the Pl.2 surface and topped by the lower Pleistocene surface Ple.1 (1.7 Ma), which occurs as a high-amplitude seismic reflector over the entire study area (Figs. 5 and 6). Ple.1 is irregular, unconformable and merges with Pl.2 in the upper slope whilst it is conformable and continuous in the basin (Figs. 3, 5, 7 and 9). In the south (Figs. 5 and 8), the unit consists of stacked concave lenticular bodies of low- to medium-amplitude chaotic facies bounded at the base and at the top by higher-amplitude reflectors (SF-4, Table 2). SU-7 is preferentially deposited in the concave depression formed by the moat of the SU6 drift and does not extend further into the basin. Well 1007 indicates that SU-7 consists of peloidal and aragonite coarse-grained mud-to grain-dominated debrites, which are rich in corals debris, red algae and shelf fauna (Eberli et al., 1997a). Lenticular calcidebrites progressively migrate upslope, showing a net back-stepping geometry (Fig. 5). Along strike, debrites form amalgamated convex-up lens that are up to $100 \mathrm{~m}$-wide and extend northward over $50 \mathrm{~km}$ (Fig. 8). These deposits seem preferentially backfilling inherited collapse-related depression of the Pliocene MTCs (Principaud et al., 2015) as they migrate further north.

SU-7 is clearly thinner in the north than in the south but shows at both locations similar architectural and sedimentological patterns, with grain-dominated stacked lobate SF-4 (Austin et al., 1986) trapped upslope into the moat of the former SU-6 drift (Figs. 6-10).

\section{SU-8: Pleistocene (1.7 Ma)-Present-day}

SU-8 is bounded at the base by the Ple.1 surface and the present seafloor at the top (Figs. 57). The slope displays a steep stranded progradational wedge (thickness $\sim 150 \mathrm{~ms}$ ) that progressively thins to the west and terminates over $17 \mathrm{~km}$ from the slope edge (Figs. 3 and 5). In the south, the wedge consists of sub-parallel, semi-continuous sigmoidal clinoforms of medium- to high-amplitude that downlap the Ple-1 surface (SF-5, Table 2) (Figs. 6 and 8). At wells 1003, 1004 and 1005, the wedge shows a down-slope facies transition from (i) slightlyto moderately dolomitized peloidal mudstones, to wakestones rich in aragonite needles along the upper slope, (ii) an alternation of last one with intervals of grey wakestones to packstones, 
grainstones and floatstones along the middle slope and (iii) peloidal bio-wackestones, packstones to floatstones with aragonite matrix and some lithoclasts intervals along the lower slope.

In the north, SU-8 also shows stacked lobate geometries containing grainstones rich in coral debris (SF-4) that accumulated above SU-7 (Figs. 6-9). The basinal deposits consist of a massive vertical succession of continuous, sub-parallel and low-amplitude reflectors (SF-2) that onlap Ple.1 surface in the north (Figs. 6,7 and 9) but interfinger the wedge in the south (Figs. 3 and 5).

\section{DISCUSSION}

\section{Paleogeography and physiography of the northwestern Great Bahama Bank}

The seismic facies analysis and geometry of individual seismic units are keys for tentatively reconstructing the paleogeographical evolution of the northwesterly slope-to-basin system of the GBB during the Neogene - Quaternary. The physiography and depositional history are illustrated using a series of isochron and isochore maps (in time) for the respective SU-1 to SU-8 seismic units (Figs. 11 and 12):

\section{Late Oligocene - Burdigalian ( 5 m.y.): Initiation of the Neogene slope-apron (SU-1)}

The SU-1 highlights two types of strike-limited depositional slope morphology, which are separated by the Bimini embayment. The south is characterized by parallel-margin escarpment faults on which strata passively onlap (Eberli \& Ginsburg, 1989), whilst the northern shelf displays a continuous accreting shelf-slope profile (Eberli \& Ginsburg, 1987). Such escarpment marginal morphology in the south may have implied a long-lived emergence at the top of the Bimini Bank and considerable downward by-pass of sediments into the basin (Playton et al., 2010) (Fig. 11.A).

The northern mud- to grain-dominated apron lies over more than $100 \mathrm{~km}$ towards the south, whilst the southern wedge is an apron dominated by aggrading muddy facies expanding westward. Both slope deposits merge in a NE-SW deep basinal area where they laterally interfinger with nannofossil-rich hemipelagic oozes (Figs. 6, 11A and 12A).

The Paleogene was a period of tectonic dislocation of the GBB, marked by the individualization of the Bimini Embayment that forms a large and transverse fault-bounded NE-SW oriented axial graben (Eberli \& Ginsburg, 1988, 1989). This structural fragmentation also resulted in scattered peripherical blocks outboard (Bergman, 2005). Some block relics formed buried topographic highs prior to the Aquitanian seafloor in the northern part of the 
study area (Figs. 11B-D and 12B-D), inducing a hummocky topography with differential subsidence during Neogene deposition. This physiographic configuration results in a $17 \mathrm{~km}$ wide and $60 \mathrm{~km}$ long depression at the southwestern limb of the Bimini Bank (Figs. 11A and $12 \mathrm{~A})$.

\section{Burdigalian - Langhian ( 3 m.y.): Northern slope-apron development (SU-2)}

SU-2 shows rapid variations of depositional slope types along strike $(<50 \mathrm{~km})$. It is marked by the onset of a slope apron development in the northern area that prograde towards the $\mathrm{W}$ and SW until the Upper Serravallian (Figs. 11B-D and 12B-D). The southwesterly slope forms a steep $\left(\sim 2.5^{\circ}\right)$ and narrow physiography, whilst the northwest slope displays a more common gentle ramp-like apron $\left(\sim 1^{\circ}\right)$ built up by prevailing sheet-like coarse-grained calciturbidite deposits. MTCs at the base-of-slope of the southwesterly flank of the northern Bimini Bank constitute the onset of successive slope failures, instabilities and large-scale collapse deposits creating abrupt scar and depression upslope. The escarpment margin persists in the south and terminates $50 \mathrm{~km}$ northward at the output of the Bimini embayment, which still forms a physiographic reentrant at the end of Langhian (Figs. 11B and 12B).

This architectural configuration may have caused large variations in sedimentation rates along slope during the Aquitanian-Langhian time interval, with a more significant material exportation in the north (Fig. 6).

Langhian - Serravallian ( 4 m.y.): Instability to the north and slope-apron development in the south $(S U-3)$

The SU-3 is marked by two major events that occurred simultaneously and interacted to form the slope to basin physiography.

(1) The establishment of contourite drifts has been identified all across the Florida Straits at around $15 \mathrm{Ma}$, illustrating the influence of a bottom-current upon the sediments distribution that flowed along the slope (Mullins et al., 1980, 1987, 1988; Bergman, 2005) (Fig. 1). Although current swept were identified in the north of the GBB (Bergman, 2005), no important contourite drift sedimentation was evidenced. Here, seismic observations show that the Santaren Drift expanded all along northwestern GBB slope, forming a continuous and correlative massive feature onlapping the SU-2 slope-apron over more than $150 \mathrm{~km}$ along strike (Figs. 6, 11D and 12C). This is consistent with results of Austin et al. (1986) and Schlager et al. (1988), who describe bottom-current deposits for this period in ODP well 626. 
The widespread extension of the Santaren Drift coincides with a regional paleooceanographic re-organization all along GBB, resulting in the initiation of the "modern" Loop Current/Gulf Stream circulation (Mullins et al., 1987) (Fig. 13).

(2) Meantime, the northern slope-apron continued to prograde towards the W and SW but shows different slope-angle through time. This slope steepened, probably as the result of a widespread increase of sedimentation rates during SU-3. The Serravallian was the period during which the highest sedimentation rates are measured $(13-18 \mathrm{~cm} / \mathrm{kyr}$ in ODP wells 1007-1003 and 1005) according to Eberli et al. (1997a). The steep slopes, together with high sedimentation rate, may have locally caused upslope failure and triggered large-collapse events (Fig. 11C). Although the estimated slope angle is relatively low $\left(\sim 3.5^{\circ}\right)$, MTCs and associated debrites show coarse grain-supported re-sedimented material.

The Serravallian interval illustrates a widespread homogeneity of depositional slope systems, with the regional development of a strike-continuous accretion margin across the entire study area. Similar architectural style changes have been also described in the Maiella Platform in Italy, where the escarpment margin has been interpreted as passing upwards into an accretion slope apron (Eberli et al., 1993; Borgomano, 2000), suggesting a common depositional slope evolution in passive margins.

Serravallian - Messinian ( 4 m.y.): Slope-apron retreat and encroachment of the contourite drift (SU-4)

The Mid- to Late Miocene was marked by a westward progradation of the carbonate platform, which was also characterized by a continuous-strike accreting slope over the GBB (Eberli \& Ginsburg, 1987) (Figs. 3, 11D and 12D). Although slope aprons accreted with the accumulation of prevailing muddy periplatform ooze and grain-supported calciturbidites sheets during the Upper Miocene, they differed in thickness and declivity. The northern apron was almost flat $\left(\sim 1^{\circ}\right)$ whilst the southern apron slope angle ranged between $2.6^{\circ}$ and $4^{\circ}$ (Betzler et al., 1999). According to Bernet et al. (2000), the upbuilding of the upper to midslope apron in the south resulted from the vertical stacking of calciturbidites during highfrequency highstand and lowstand conditions (Fig. 12C). Sedimentation rates were clearly higher in the uppermost part of SU-4 than in the lower part (respectively around $13 \mathrm{~cm} / \mathrm{kyr}$ and $4 \mathrm{~cm} / \mathrm{kyr}$ in 1007 ODP well) (Eberli et al., 1997a), indicating that the platform probably shed the slope when the progradation was at a maximum. Meantime, as the Santaren Drift progressively migrated upslope because of the likely persistence of along-slope bottom- 
currents during the Upper Miocene, they prevented further free-expansion of re-sedimented materials towards the west.

Long-duration emersion was evidenced at the top of SU-4 by a karstified dolomitized surface and shallow incised valleys in the Unda well (Kenter et al., 2001). Simultaneously, along the upper slope at the Clino well, an iron-manganese stained hardground indicated a major sedimentary hiatus at the Miocene/Pliocene boundary (Eberli et al., 1997a). These observations indicated a sharp decrease in sediment export from the platform at the end of SU-4, when the shelf was entirely emerged (see also Grammer \& Ginsburg (1992)). The Santaren Drift still migrated upslope during this period (Fig. 11D)

\section{Messinian - Early Pliocene ( 2 m.y.): Generalized drowning of the platform (SU-5)}

On the shelf edge of the southern GBB platform, just above the Me surface, Clino and Unda wells both reveal packstones and mixed peloidal-skeletal packstones to grainstones rich in deep water foraminifera, indicating a temporal flooding of the platform during the Early Pliocene (Kenter et al., 2001). This interpretation is consistent with nannofossil chalk and condensed sections preserved along the slope and basin within SU-5, testifying an increase in water depths over the GBB. This event is interpreted as being a transgression that subsequently caused a significant change in the ecosystems on the carbonate platforms (Kenter et al., 2001). The flooding may have also coincided with the final backfilling of the Strait of Andros and Bimini embayment inboard (Eberli \& Ginsburg, 1988).This sudden bathymetric increase resulted in a slight eastward retreat of slope aprons with a moderate smoothing of the shelf-slope profiles. It may be linked to a minor upslope migration of the Santaren Drift and, at some extent, might have triggered the first large-scale collapses in the central area (Principaud et al., 2015) (Figs. 10, 11E-F and 12E).

Early Pliocene - Late Pliocene ( 1 m.y.): Maximum encroachment of the contourite drift and confined debrites ( $S U-6 / 7)$

SU-6 is characterized by the maximum aggradation and progradation of the contourite drift towards the platform, with depocenters essentially developed in the southern area (Figs. 11F, G). This thickness variation suggests a difference in sedimentation rates along strike (respectively 3-5 cm/kyr in the north and $12 \mathrm{~cm} / \mathrm{kyr}$ in the south; Eberli et al. (1997a)) that may be linked to the source change in production on the platform and/or the variation of the 
distance from the source. Moreover, the southern depocenter might have been created by the confinement in the Santaren Channel, which unconfined when it merged with the Florida Straits. This event was relatively short, ranging over less than 1 m.y. and might have been linked to intensification of currents although eustatic conditions that were not well constrained during this time (Fig. 13). Faugères \& Mulder (2011) also demonstrate the relationship between the dip of the seafloor and contour-current velocity. Indeed, when the slope was steeper, the velocity of the current tended to increase due to the reduction of the seafloor surface swept by the bottom current.

Laterally, extensive debrites-dominated slope-aprons developed during the Late Pliocene as amalgamated stacked debrites detached from the outer margin (Fig. 5). The upper slope is therefore interpreted as a by-pass zone showing numerous deep ( 50-100 ms TWT) V-shape canyons (Fig. 10). The lenticular shape of debrites resulted in a topographic compensation stacking style that forms an accretionary to back-stepping geometry in an upslope direction, causing a progressive decrease of off-shelf transport energy. Debrites mostly form a large strike-continuous belt, as the result of a confined sedimentary backfilling in the former mounded geometry of the Santaren drift moat (Fig. 12G). In the north, high rates of material exportation freely expanded up to the rear of the drift.

The onset of a steep prograding margin occurred over the GBB during the Late Pliocene as a result of a combination of eustatic highstand (Eberli, 2000) and off-bank transportation of coarse peloidal but non-skeletal deposits (Kenter et al., 2001). Drastic changes in biological ecosystems (first appearance of the Caribbean reef-building coral Acropora palmata; McNeill et al., 1997) coevally operated on the platform as a result of worldwide climatic cooling (Kenter et al., 2001) (Fig. 13).

\section{Pleistocene - Present-day ( 1.7 m.y.): Establishment of a new slope-apron (SU-8)}

The Pleistocene corresponds to the second and last episode of prograding reefal platform growth, characterized by short sigmoidal slope clinoforms with steep slopes (around $45^{\circ}$ in the uppermost part of the upper slope according to Betzler et al. (1999)) over the Great Bahama Bank (Fig. 3) (Eberli \& Ginsburg, 1987; Schlager et al., 1988; Eberli \& Ginsburg, 1989). Off-bank transport was likely favored by prevailing NNW blowing winds and tidal currents (Wilson \& Roberts, 1992, 1995) that deposited very coarse upper shelf-derived skeletal grains on the upper slope (Kenter et al., 2001), and caused the over-steepening of the adjacent slope (Kenter et al., 2001). High sedimentation rates $(10 \mathrm{~cm} / \mathrm{kyr}$ at ODP well 1003 
according to Eberli et al. (1997a)) suggest voluminous short-time exportation of material. Although the shelf edge showed a significant basinward stepping migration compared to the former SU-7 (Eberli \& Ginsburg, 1989), slope sedimentation was restricted in the vicinity of shelf edge as a consequence of slope heightening and over-steepening (Fig. 11H). SU-8 Shelf-slope progradation is interpreted as resulting from successive glacial and inter-glacial episodes (Eberli, 2000).

The middle part of the study area was affected by important slope collapses and mass wasting deposits whilst basinal sedimentation was mostly dominated by the renewal of periplatform ooze and less active deposition by contourite drifts (Fig. 12H).

Depositional model and control parameters of Neogene-Quaternary carbonate gravity-flows along the slope of the northwestern Great Bahama Bank

The Neogene to Quaternary deep-water carbonate system of the GBB accounted for a particular dynamic slope apron evolution that distinctively displayed successive slope physiography with highly diversified facies and slope angles along strike. Figure 14 illustrates the strike variability of spatial facies distributions of the shelf-slope-basin of the GBB system from the Mid-Miocene to present-day. Figure 14 also shows the relationships between slope morphology, average slope declivity, type of resedimented materials and grain-size prevalence.

The Middle to Late Miocene (Burdigalian to Upper Messinian) slope system can be regionally compared with a mud- to grain-supported slope apron or accretionary margin, according to the respective classification of Mullins \& Cook (1986) and Playton et al. (2010), where slope angle averages between $\sim 2.6^{\circ}$ and $4^{\circ}$ along strike for $\sim 10 \mathrm{~m}$.y. (Betzler et al., 1999) (Fig. 14A-B). The Early Pliocene flooding marks a break in the GBB slope evolution as it caused the temporary stop of slope apron growth and the smoothing of the inherited paleo-topography (Fig. 14C). Then, abundant strike-continuous coarse skeletal calcidebrites lens occurred during the Late Pliocene. These were detached from the shelf edge via an erosional "by-pass" upper slope zone, and might coincide to the base-of-slope apron system of Mullins \& Cook (1986) or the debris-dominated slope apron model of Playton et al. (2010) (Fig. 14D). The Pleistocene showed the return of even steeper slope morphology, characterized by very short prograding clinoformal aprons (Fig. 14E). 
This study shows that several morphologic and stratigraphic features, like MTC occurrences and drift deposits, have been underestimated and poorly integrated in the previous depositional models proposed for the GBB (Mullins \& Cook, 1986; Betzler et al., 1999, 2000; Eberli, 2000; Playton et al., 2010). Here, these features are considered to be the most important control parameters affecting the spatial distribution of gravity-flow carbonate deposits. Analysis of such parameters therefore suggests a re-evaluation in the morphological style of depositional systems to improve understanding of deep-water carbonate deposition and distribution along the GBB.

Role of large-collapse deposits upon the slope apron physiography

Although no lateral slope declivity or grain-size prevalence variations were observed along GBB slope apron during the Mid- to Late Miocene, the style of foreslope morphology may have varied locally. The SW flank of the northern Bimini Bank provides a good example of a narrow and short accreting slope apron that passes rapidly into adjacent larger and more extensive foreslope over a distance of less than $30 \mathrm{~km}$. This area was affected by successive upslope failures during at least 10 m.y., which caused the deposition of gigantic $(>25 * 60$ $\mathrm{km}$ ) MTCs downslope and erosional scars upslope. As a consequence of repetitive collapses, a significant amount of disorganized resedimented materials made up of isolated megablocks, boulder complexes, cohesive calcidebrites and coarse turbidites occurs at the base-ofslope domain, forming a hummocky basin-floor topography up to $50 \mathrm{~km}$ in the basin. Similar megabreccias and debrite-dominated slope deposits have been previously described as deposits of the original base-of-slope apron by Mullins \& Cook (1986). The carbonate sediments that immediately postdate the collapses rapidly backfilled the nested excavations formed by the upper foreslope removal to compensate the depression left at the toe of MTC scars. Backfilling sediments were forced to incline downslope over a short distance, forming higher slope-angle clinoforms that initiated subsequent instabilities. Conversely, the adjacent mud-dominated low-angle slope aprons accreted over even larger distances without being affected by upslope instabilities.

The causes of these large-scale collapse events during the Mid- to Late Miocene over a spatially restricted area remains difficult to determine. Several statements can, however, be highlighted with the regard of our current understanding of the GBB evolution: 
(1) The regional slope apron does not indicate local declivity increase but remains constant all along the GGB slope (i.e. $<4^{\circ}$ ). Megabreccia formation therefore does not appear to have been triggered by slope oversteepening. Spence \& Tucker (1997) suggest, however, that the initiation of large megabreccias does not also require metastable angular conditions (e.g. exceed of angle-of-repose in grain- to debrites-dominated foreslope) prior to failure in mudsupported low-angle slopes. Submarine instabilities and sliding may be caused by decreasing sediment shear strength at parallel-seafloor décollement planes, which commonly occur in mud deposits undergoing fluid-overpressure at the upper to mid-slope. Fluids may have been rapidly trapped as sedimentation rates upon the slope would have been high. Furthermore, $100 \mathrm{~km}$-wide catastrophic slope failures have been also observed in Mid-Miocene deposits from the distally steepened ramp of the West Florida margin (Mullins et al., 1986), testifying that large MTCs have occurred elsewhere in the same period of time along a leeward margin.

(2) The prevalent grain-size of the foreslope does no show significant variations along strike and does not justify differences in slope deposit cohesion and/or lithification along strike.

(3) Burdigalian to Serravallian times recorded the highest rates of slope sedimentation over the GBB (Eberli et al., 1997a) that coincide with eustatic-derived highstands where the platform carbonate factory rapidly delivered a maximum amount of downslope overpressured material ("Highstand shedding”, Droxler \& Schlager (1985), Schlager et al. (1994), Kendall \& Schlager (1981), Jorry et al. (2010)). Here, even whether MTCs seems to be triggered at the end of each depositional sequence when sedimentary influxes are the highest, the stratigraphic frame is not accurate enough to conclude with certainty.

(4) The early cementation can also be considered as a major factor in MTCs. Principaud et al. (2015) show that Plio-pleistocene MTCs all glided along a common privileged décollement surface which coincided with a regional diagenetic key stratigraphic surface. In ODP Leg 166 wells, early cementation is characterized by well-lithified intervals (i.e., hardgrounds) which are found almost exclusively in glacial lowstand deposits and interpreted to have formed at or near the seafloor (Malone et al., 2001). The lithified hardgrounds produce abrupt shifts in the index properties and shear strengths with unlithified to partially lithified portions. The low shear strength just above the lithified horizons may be a potential weak detachment layer along which slope failure can occur. 
Development and role of bottom current upon the architectural evolution of the northern Great Bahama Bank

Various authors have recognized the importance of bottom currents in deep-water realms, pointing out a much more dynamic environment than earlier suggested (e.g., Bergman, 2005; Faugères \& Stow, 2008; Faugères \& Mulder, 2011; Betzler et al., 2014a). The Mid-Miocene was marked by the onset of significant bottom-flow circulation that modified the seafloor physiography by forming contourite drifts in the Florida Straits (Fig. 14) (Mullins \& Neumann, 1979; Mullins et al., 1980, 1987; Bergman, 2005). In the study area, the Santaren Drift was initiated during the Langhian and evolved until present-day throughout successive phases of growth, and lateral migration. The occurrence and emplacement of such a major basinal feature coincides with a general oceanographic re-organization of the Northern Hemisphere that operated around $15 \mathrm{Ma}$, which has been interpreted as resulting from plate tectonic movements in the Caribbean region (Mullins \& Neumann, 1979; Mullins et al., 1987). Indeed, the shoaling of the Isthmus of Panama and the progressive closure of the CAS started during the Langhian, causing the onset of the North Atlantic deep water (NADW) circulation and the intensification of the Loop Current in the Gulf of Mexico (Fig. 13) (Mullins et al., 1987). During the Miocene, westward down-flowing turbidity currents depositing calciturbidites along the slope, coevally interfingered with muddy contourites deposited by the Santaren Drift that progressively migrated towards the lower to mid-slope. Bottom currents were likely not strong enough to enable the upslope migration of the contourite deposits, which therefore only in the basin and the lowermost part of the slope.

The final closure of the CAS at about 4.7 and 2.7 Ma induced drastic changes in the global thermohaline circulation that may have caused the Late Pliocene North Hemisphere Glaciation (Haug \& Tiedemann, 1998; Haug et al., 2001; Bartoli et al., 2005; Steph et al., 2006). This event also coincides with the rapid upslope migration of the Santaren Drift along the Mid- to Late Pliocene slope apron, where contourites rapidly prograded eastwards to form a concave sub-basin at the moat position (Fig. 12C). The subsequent Late Pliocene debrite lens, caused by a sea-level drop, were trapped and confined within the drift-derived moat, forming a strike continuous coarse facies belt along the mid-slope of the GBB. Similar confinements of MTCs formed by the aggrading contourites have been described by Principaud et al. (2015) for the Pliocene-Pleistocene. 


\section{CONCLUSIONS}

New high-quality multichannel seismic data, together with the integration of ODP wells results, have enabled us to enhance understanding of the evolution of the northwestern slope of the Great Bahama Bank carbonate slope-to-basin during the Neogene-Quaternary.

The GBB slope developed as an extensive strike-continuous progradational slope-apron system characterized by mud-supported calciturbidites during the Miocene until a major flooding event in the Early Pliocene caused the temporal cessation of slope apron growth and the smoothing of the inherited paleo-topography. In the northern GBB, large collapse-events, typified by kilometric-across MTCs and coarse debrites, locally led the shortening and oversteepening of the slope apron. Successive upslope failures occurred during the Miocene, causing significant local variability in the slope physiography along strike. The Late Pliocene was marked by a return of accreting slope morphology, characterized by significant by-pass and downslope movement of coarse carbonate debrites. Debrite deposition was detached from the shelf edge, building up a base-of-slope apron system along the GBB. The Pleistocene rather evolved as a progradational slope-apron, characterized by a steep slope angle until present-day. Recent large MTCs occurred locally and are interpreted as being concomitant with the steep slope physiography.

This study also highlights the importance of drift deposits upon the distribution of downslope margin-derived calciturbidites, debrites, and collapse-related MTCs that repetitively occurred during the last 25 m.y. When contourites formed large mounded features upslope with a welldeveloped moat depression, they trapped and confined downslope deposits, which could not expand freely into the basin. By extension, contourite deposits significantly prevented the natural development of slope physiography as traditionally illustrated in the literature. Contourite drifts are intimately linked with bottom-currents which are known to reflect a global oceanographic re-organization and climate changes in the Northern Hemisphere between $15 \mathrm{Ma}$ until $2.7 \mathrm{Ma}$, simultaneously with the closure of the CAS.

\section{ACKNOWLEDGEMENTS}

The authors would like to thank the captain and crew of the RV Le Suroit for the quality of the acquired data and Ifremer-Genavir for the Carambar cruise organization and onboard data pre-processing. This work has been supported by the French INSU program "Actions Marges." The author was awarded a grant by the company Total through the Cifre program. The authors are grateful to Stephan Jorry and the second anonymous reviewer for their constructive criticisms, comments, and suggestions which helped to considerably improve 
this paper. Special thanks to David Peacock and Laurent Gindre-Chanu for the English reviewing.

\section{CONFLICT OF INTEREST}

No conflict of interest declared.

\section{REFERENCES}

Anselmetti, F.S., Eberli, G.P. \& Ding, Z.-D. (2000) From the Great Bahama Bank into the Straits of Florida: a margin architecture controlled by sea-level fluctuations and ocean currents. Geological Society of America Bulletin, 112, 829-844.

Atkinson, L.P., Berger, T., Hamilton, P., Waddell, E., LeAman, K. \& Lee, T.N. (1995) Current meter observations in the Old Bahama Channel. Journal of Geophysical Research: Oceans, 100, 8555-8560.

Austin, J.A., Schlager, W. \& al. (1986) Proceedings of the Ocean Drilling Program, initial reports, Leg 101. College Station, Texas, Ocean Drilling Program, 101, 569 p.

Bartoli, G., Sarnthein, M., Weinelt, M., Erlenkeuser, H., Garbe-Schönberg, D. \& LEA, D.W. (2005) Final closure of Panama and the onset of northern hemisphere glaciation. Earth and Planetary Science Letters, 237, 33-44.

Bergman, K.L. (2005) Seismic analysis of paleocurrent features in the Florida Straits; insights into the paleo-Florida current, Upstream tectonics, and the Atlantic-Caribbean connection. $\mathrm{PhD}$ thesis, University of Miami, $189 \mathrm{p}$.

Bernet, K.H., Eberli, G.P. \& Gilli, A. (2000) Turbidite frequency and composition in the distal part of the Bahamas transect. In: Proceedings of the Ocean Drilling Program, Scientific Results, vol. 166 (Ed. by P. K. Swart, G. P. Eberli, M. J. Malone \& F. J. Sarg), College Station, Texas, Ocean Drilling Program, 166, 45-60.

Betzler, C., Reijmer, J.J.G., Bernet, K., Eberli, G.P. \& Anselmetti, F.S. (1999) Sedimentary patterns and geometries of the Bahamian outer carbonate ramp (MioceneLower Pliocene, Great Bahama Bank). Sedimentology, 46, 1127-1143.

Betzler, C., Pfeiffer, M. \& Saxena, S. (2000) Carbonate shedding and sedimentary cyclicities of a distally steepened carbonate ramp (Miocene, Great Bahama Bank). International Journal of Earth Sciences, 89, 140-153.

Betzler, C., Lindhorst, S., Eberli, G.P., Lüdmann, T., Möbius, J., Ludwig, J., Schutter, I., Wunsch, M., ReIJMer, J.J.G. \& HÜBSCheR, C. (2014) Periplatform drift: 
the combined result of contour current and offbank transport along carbonate platforms. Geology, 42, 871-874.

BORGOMANO, J.R.F. (2000) The Upper Cretaceous carbonates of the Gargano-Murge region, southern Italy: A model of platform-to-basin transition. AAPG Bulletin, 84, 1561-1588.

Calais, E. \& De LéPINAY, B. (1995) Strike-Slip Tectonic Processes in the Northern Caribbean between Cuba and Hispaniola (Windward Passage). Marine Geophysical Researches, 17, 63-95.

COATES, A.G., JACKSON, J.B.C., COLLINS, L.S., CRONIN, T.M., DOWSETT, H.J., BYBELL, L.M., JUNG, P. \& OBANDO, J.A. (1992) Closure of the Isthmus of Panama: the near shore marine record of Costa Rica and western Panama. GSA Bulletin, 104, 814-828.

Coniglio, M. \& DiX, G.R. (1992) Chapter 18. Carbonate slopes. In: Facies models: Response to sea-level change (Ed. by R. G. Walter \& N. P. James). Geological Association of Canada, 349-374.

Correa, T.B.S., Grasmueck, M., Eberli, G.P., Reed, J.K., Verwer, K. \& Purkis, S.A.M. (2012) Variability of cold-water coral mounds in a high sediment input and tidal current regime, Straits of Florida. Sedimentology, 59, 1278-1304.

Corso, W., Schlager, W., Flügel, E. \& Buffler, R.T. (1985) A reinterpretation of an Early Cretaceous carbonate platform on Abaco Knoll, Northern Bahamas. Gulf Coast Association of Geological Societies Transactions, 35, 29-38.

Crevello, P.D. \& Schlager, W. (1980) Carbonate debris sheets and turbidites, Exuma Sound, Bahamas. Journal of Sedimentary Petrology, 50, 1121-1147.

DENNY III, W.M., Austin, J.A. \& BufFlER, R.T. (1994) Seismic stratigraphy and geologic history of Middle Cretaceous through Cenozoic rocks, southern Straits of Florida. American Association of Petroleum Geologists, 78, 461-487.

DuQue-CARO, H. (1990) Neogene Stratigraphy, Paleoceanography and Paleobiogeography in Northwest South America and the Evolution of the Panama Seaway. Palaeogeography, Palaeoclimatology, Palaeoecology, 77, 203-234.

EBERLI, G.P. (2000) The record of Neogene sea-level changes in the prograding carbonates along the Bahamas Transect- Leg 166 Synthesis. In: Proceedings of the Ocean Drilling Program, Scientific Results (Ed. by P. K. Swart, G. P. Eberli, M. J. Malone \& F. J. Sarg), College Station, Texas, Ocean Drilling Program, 166, 164-177. 
EBERLI, G.P. \& GINSBURG, R.N. (1987) Segmentation and coalescence of Cenozoic carbonate platforms, northwestern Great Bahama Bank. Geology, 15, 75-79.

EBERLI, G.P. \& GinsBURG, R.N. (1988) Aggrading and prograding infill of buried Cenozoic seaways, northwestern Great Bahama Bank. In: Atlas of Seismic Stratigraphy (Ed. by A. W. Bally). American Association of Petroleum Geologists Studies in Geology, 2, $97-$ 103.

EberLI, G.P. \& GinsbURG, R.N. (1989) Cenozoic progradation of northwestern Great Bahama Bank, a record of lateral platform growth and sea-level fluctuations. In: Controls on Carbonate Platform and Basin Systems ( Ed. by P. D. Crevello, J. A. Wilson, J. F. Read \& F. J. Sarg). Society of Economic Paleontologists and Mineralogists Special Publication, 44, 339-351.

Eberli, G.P., Bernoulli, D., SAnders, D. \& Vecsei, A. (1993) From aggradation to progradation: the Maiella Platform Margin (Abruzzi, Italy). In: Cretaceous Carbonate Platforms (Ed. by J. T. Simo, R. W. Scott \& J.-P. Masse). American Association of Petroleum Geologists Memoir, 56, 213-232.

Eberli, G.P., Swart, P.K., Malone, M.J. \& al. (1997a) Proceedings of the Ocean Drilling Program, initial reports, Leg 166. College Station, Texas, Ocean Drilling Program, $166,850 \mathrm{p}$.

Eberli, G.P., Swart, P.K., McNeill, D.F., Kenter, J.A.M., Anselmetti, F.S., Melim, L.A. \& Ginsburg, R.N. (1997b) A synopsis of the Bahamas Drilling Project: Results from two deep core borings drilled on the Great Bahama Bank. In: Proceedings of the Ocean Drilling Program, initial reports, Leg 166 (Ed. by G. P. Eberli, P. K. Swart, M. J. Malone et al.). College Station, Texas, Ocean Drilling Program, 166, 23-41.

FAugÈRes, J.-C. \& Mulder, T. (2011) Chapter 3: Contour currents and contourite drifts. In: Deep-sea sediments (Ed. by H. Huneke \& T. Mulder). Developments in Sedimentology, $63,149-214$.

FAugèRes, J.-C. \& Mulder, T. (2014) Chapter 14. Contourite drifts: nature, evolution and controls. In: Contourites (Ed. by M. Rebesco \& A. Camerlenghi). Developments in Sedimentology, 60, 257-288.

Faugères, J.-C., Stow, D.A.V., Imbert, P. \& Viana, A.R. (1999) Seismic features diagnostic of contourite drifts. Marine Geology, 162, 1-38.

Flower, B.P. \& KennetT, J.P. (1994) The Middle Miocene Climatic Transition: East Antarctic Ice Sheet Development, Deep Ocean Circulation and Global Carbon Cycling. Palaeogeography, Palaeoclimatology, Palaeoecology, 108, 537-555.

This article is protected by copyright. All rights reserved. 
GINSBURG, R.N. (2001) The Bahamas Drilling Project: background and acquisition of cores and logs. In: Subsurface Geology of a Prograding Carbonate Platform Margin, Great Bahama Bank: Results of the Bahamas Drilling Project (Ed. by R. N. Ginsburg). Society of Economic Paleontologists and Mineralogists Special Publication, 70, 3-13.

Gradstein, F.M., OgG, J.G., Smith, A.G., Bleeker, W. \& Lourens, L.J. (2004) A new geologic time scale, with special reference to Precambrian and Neogene. Episodes, 27, 83-100.

Grammer, G.M. \& GinsburG, R.N. (1992) Highstand versus lowstand deposition on carbonate platform margins: insight from Quaternary foreslopes in the Bahamas. Marine Geology, 103, 125-136.

Grasmueck, M., Eberli, G.P., Viggiano, D.A., Correa, T., Rathwell, G. \& Luo, J. (2006) Autonomous underwater vehicle (AUV) mapping reveals coral mound distribution, morphology, and oceanography in deep water of the Straits of Florida. Geophysical Research Letters, 33, 1-6.

Haug, G.H. \& TiEdemann, R. (1998) Effect of the formation of the Isthmus of Panama on Atlantic Ocean thermohaline circulation. Nature, 393, 673-676.

Haug, G.H., Tiedemann, R., Zahn, R. \& Ravelo, A.C. (2001) Role of Panama Uplift on oceanic freshwater balance. Geology, 29, 207-210.

Hine, A.C. \& NEumAnN, A.C. (1977) Shallow carbonate-bank-margin growth and structure, Little Bahama Bank, Bahamas. American Association of Petroleum Geologists Bulletin, 61, 376-406.

Hine, A.C., Wilber, R.J., BAne, J.M., Neumann, A.C. \& LoRenson, K.R. (1981a) Offbank transport of carbonate sands along open, leeward bank margins: Northern Bahamas. Marine Geology, 42, 327-348.

Jo, A. (2013) Carbonate slope morphology and sedimentary processes along southwestern Great Bahama Bank. Master Thesis, University of Miami, 121 p.

KeIGWIN, L. (1982) Isotopic Paleoceanography of the Caribbean and East Pacific: Role of Panama Uplift in Late Neogene Time. Science, 23, 217.

KELLER, G. \& BARRON, J.A. (1983) Paleoceanographic Implications of Miocene DeepSea Hiatuses. Geological Society of America Bulletin, 94, 590-613.

Kendall, C.G.S.C. \& Schlager, W. (1981) Carbonates and relative changes in sea level. Marine Geology, 44, 181-212.

KENTER, J.A.M. (1990) Carbonate platform flanks: slope angle and sediment fabric. Sedimentology, 37, 777-794.

This article is protected by copyright. All rights reserved. 
Kenter, J.A.M., Ginsburg, R.N. \& Troelstra, S.R. (2001) The Western Great Bahama Bank: sea-level-driven sedimentation patterns on the slope and margin. In: Subsurface Geology of a Prograding Carbonate Platform Margin, Great Bahama Bank : Results of the Bahamas Drilling Project (Ed. by R. N. Ginsburg). Society of Economic Paleontologists and Mineralogists Special Publication, 70, 61-100.

LADD, J.W. \& SHERIDAN, R.E. (1987) Seismic stratigraphy of the Bahamas. American Association of Petroleum Geologists Bulletin, 71, 719-73.

Leaman, K.D., Vertes, P.S., Atkinson, L.P., Lee, T.N., Hamilton, P. \& Waddell, E. (1995) Transport, potential vorticity, and current/temperature structure across Northwest Providence and Santaren Channels and the Florida Current off Cay Sal Bank. Journal of Geophysical Research, 100, 8561-8569.

LeE, T.N., Leaman, K.D. \& Williams, E. (1995) Florida current meanders and gyre formation in the Straits of Florida. Journal of Geophysical Research, 100, 8607-8620.

MALONE, M.J., SLOWEY, N.C. \& HENDERSON, G.M. (2001) Early diagenesis of shallow-water periplatform carbonate sediments, leeward margin, Great Bahma Bank (Ocean Drilling Program Leg 166). GSA Bulletin, 113, 881-894.

MASAFERRO, J.L. (1997) Interplay of tectonism and carbonate sedimentation in the Bahamas Foreland Basin. Unpublished Dissertation, University of Miami, 147 p.

MAsAferro, J.L. \& EberLI, G.P. (1995) Tectonic destruction and segmentation of the Bahamas Carbonate Platform. Geological Society of America Bulletin Abstracts with Programs, 81.

MASAFERRO, J.L. \& EberLI, G.P. (1999) Jurassic-Cenozoic structural evolution of the southern Great Bahama Bank. In: Caribbean Basins (Ed. by P. Mann). Sedimentary Basins of the World, 4, 167-193.

Masaferro, J.L., Poblet, J., Bulnes, M., Eberli, G.P., Dixon, T.H. \& McClay, K.E.N. (1999) Palaeogene-Neogene/Present Day (?) growth folding in the Bahamian Foreland of the Cuban Fold and Thrust Belt. Journal of the Geological Society, 156, 617-631.

Masaferro, J.L., Bulnes, M., Poblet, J. \& Eberli, G.P. (2002) Episodic folding inferred from syntectonic carbonate sedimentation: the Santaren Anticline, Bahamas Foreland. Sedimentary Geology, 146, 11-24.

McNEILL, D.F., BUDD, A.F. \& BORNE, P.F. (1997) Earlier (late Pliocene) first appearance of the Caribbean reef-building coral Acropora palmate: Stratigraphic and evolutionary implications. Geology, 25, 891-894. 
Mitchum, R.M.J., Vail, P.R. \& SAngreE, J.B. (1977) Seismic stratigraphy and global changes of sea level, part 6: Stratigraphic interpretation of seismic reflection patterns in depositional sequences. In: Seismic Stratigraphy - Applications to Hydrocarbon Exploration (Ed. by C. E. Payton). American Association of Petroleum Geologists Memoir, 26, 117-133.

Mulder, T. \& CochonAt, P. (1996) Classification of offshore mass movements. Journal of Sedimentary Research, 66, 43-57.

Mulder, T. \& AleXANDER, J. (2001) The physical character of subaqueous sedimentary density flows and their deposits. Sedimentology, 48, 269-299.

Mulder, T., Ducassou, E., Eberli, G.P., Hanquiez, V., Gonthier, E., Kindler, P., Principaud, M., Fournier, F., Léonide, P., Billeaud, I., Marsset, B., Reijmer, J.J.G., Bondu, C., Joussiaume, R. \& Pakiades, M. (2012) New insights into the morphology and sedimentary processes along the western slope of Great Bahama Bank. Geology, 40, 603-606.

Mullins, H.T. (1983) Modern carbonate slope and basins of the Bahamas. In: Platform Margin and Deepwater Carbonates. (Ed. by H. E. Cook, Hine, A.C., \& Mullins, H.T.). Society of Economic Paleontologists and Mineralogists Course, 12, 4.1-4.138.

Mullins, H.T. \& COOK, H.E. (1986) Carbonate apron models: alternatives to the submarine fan model for paleoenvironmental analysis and hydrocarbon exploration. Sedimentary Geology, 48, 37-79.

Mullins, H.T. \& Neumann, A.C. (1979) Geology of the Miami Terrace and its paleooceanographic implications. Marine Geology, 30, 205-236.

Muldins, H.T., Neumann, A.C., Wilber, R.J., Hine, A.C. \& Chingurg, S.J. (1980) Carbonate sediment drifts in northern straits of Florida. American Association of Petroleum Geologists Bulletin, 64, 1701-1717.

Mullins, H.T., Heath, K.C., Van Buren, H.M. \& Newton, C.R. (1984) Anatomy of a modern open-ocean carbonate slope: northern Little Bahama Bank. Sedimentology, 31, 141-168.

Mullins, H.T., Gardulski, A.F. \& Hine, A.C. (1986) Catastrophic collapse of the West Florida carbonate platform margin. Geology, 14, 167-170.

Mullins, H.T., Gardulski, A.F., Wise, S.W. \& Applegate, J. (1987) Middle Miocene oceanographic event in the Eastern Gulf of Mexico: implications for seismic stratigraphic succession and Loop Current/Gulf Stream circulation. Geological Society of America Bulletin, 98, 702-713. 
Mullins, H.T., Gardulski, A.F., HINE, A.C., MElillo, A.J., WISE, S.W \& APPLEGATE, J. (1988) Three-dimensional sedimentary framework of the carbonate ramp slope of central West Florida: a sequential seismic stratigraphic perspective. Geological Society of America Bulletin, 100, 514-533.

NewkiRK, D.R. \& MARTin, E.E. (2009) Circulation through the Central American Seaway During the Miocene Carbonate Crash. The Geological Society of America, 37, 87-90.

PINDELL, J. (1985) Alleghenian reconstruction and subsequent evolution of the Gulf of Mexico, Bahamas, and Proto-Caribbean. Tectonics, 4, 1-39.

Pindell, J. \& Kennan, L. (2001) Kinematic evolution of the Gulf of Mexico and Caribbean. GCSSEPM Foundation 21st Annual Research Conference Transactions, Petroleum Systems of Deep-Water Basins, 193-220.

Playton, T., Janson, X. \& Kerans, C. (2010) Chapter 18: Carbonate slopes. In: Facies Models (Ed. by N. P. James \& R. W. Dalrymple), Geological Association of Canada, 449-476.

PotTer, P.E. \& Szatmari, P. (2009) Global Miocene Tectonics and the Modern World. Earth-Science Reviews, 96, 279-295.

Principaud, M., Mulder, T., Gillet, H. \& Borgomano, J. (2015) Large-scale carbonate submarine mass-wasting along the northwestern slope of the Great Bahama Bank (Bahamas): morphology, architecture, and mechanisms. Sedimentary Geology, 317, 27 42.

RENDle, R.H. \& REIJMER, J.J.G. (2002) Quaternary slope development of the western, leeward margin of the Great Bahama Bank. Marine Geology, 185, 143-164.

Reuning, L., ReIJMer, J.J.G. \& BetZler, C. (2002) Sedimentation cycles and their diagenesis on the slope of a Miocene carbonate ramp (Bahamas, ODP Leg 166). Marine Geology, 185, 121-142.

Roth, J.M., Droxler, A.W. \& KameO, K. (2000) The Caribbean Carbonate Crash at the Middle to Late Miocene Transition: Linkage to the Establishment of the Modern Global Ocean Conveyor. In: Proceedings of the Ocean Drilling Program, Scientific Results (Ed. by R. M. Leckie, H. Sigurdsson, G. D. Acton \& G. Draper), 165, 249-273.

Ross, M.I. \& SCOTESE, C.R. (1988) A hierarchical tectonic model of the Gulf of Mexico and Caribbean Region. Tectonophysics, 155, 139-168.

SARG, J.F. (1988) Carbonate sequence stratigraphy. In: Sea-Level Changes: An Integrated Approach (Ed. by C. K. Wilgus, B. S. Hastings, C. G. S. C. Kendall, H. W. 
Posamentier, C. A. Ross \& J. C. Van Wagoner), Society of Economic Paleontologists and Mineralogists Special Publication, 42, 155-188.

SCHLAGER, W. (1981) The paradox of drowned reefs and carbonate platforms. Geological Society of America Bulletin, 92, 197-211.

SCHLAGER, W. \& CHERMAK, A. (1979) Sediment facies of platform basin-transition, Tongue of the Ocean, Bahamas. In: Geology of Continental Slopes (Ed. by L. J. Doyle \& O. H. Pilkey), Society of Economic Paleontologists and Mineralogists Special Publication, 27, 193-207.

Schlager, W., Bourgeois, F., Mackenzie, G. \& Smit, J. (1988) Boreholes at Great Isaac and Site 626 and the history of the Florida Straits. In: Proceeding of the Ocean Drilling Program, Scientific Results (Ed. by J. A. Austin, W. Schlager et al.), College Station, Texas, Ocean Drilling Program, 101, 425-437.

Schlager, W., Reijmer, J.J.G. \& Droxler, A. (1994) Highstand shedding of carbonate platforms. Journal of Sedimentary Research, 64, 270-281.

Shanmugam, G. (2008) Deep-water bottom currents and their deposits. In: Contourites (Ed. by M. Rebesco \& A. Camerlenghi), Developments in sedimentology, 60, 59-81.

Sheridan, R.E., Crosby, J.T., Bryan, G.M. \& Stoffa, P.L. (1981) Stratigraphy and structure of southern Blake Plateau, Northern Florida Straits, and Northern Bahama Paltform from multichannel seismic reflection data. American Association of Petroleum Geologists Bulletin, 65, 2571-2593.

Spence, G.H. \& TuCKER, M.E. (1997) Genesis of limestone megabreccias and their significance in carbonate sequence stratigraphic models: a review. Sedimentary Geology, 112, 163-193.

Steph, S., Tiedemann, R., Prange, M., Groeneveld, J., Nürnberg, D., Reuning, L., Schulz, M. \& Haug, G.H. (2006) Changes in Caribbean surface hydrography during the Pliocene shoaling of the Central American Seaway. Paleoceanography, 21, 1-25.

Vail, P.R., Mitchum, R.M.J., Todd, R.G., Widmier, J.M., Thompson, S.I., SAngree, J.B., Budd, J.N. \& HATLELID, W.G. (1977) Seismic stratigraphy and global changes of sea level. In: Seismic Stratigraphy - Applications to Hydrocarbon Exploration (Ed. by C. E. Payton), American Association of Petroleum Geologists Memoir. 26, 49-212.

WANG, J. \& Mooers, C.N.K. (1997) Three-dimensional perspectives of the Florida Current: transport, potential vorticity, and related dynamical properties. Dynamics of Atmospheres and Oceans, 27, 135-149. 
Wilber, R.J., Milliman, J.D. \& Halley, R.B. (1990) Accumulation of bank-top sediment on the western slope of Great Bahama Bank: rapid progradation of a carbonate megabank. Geology, 18, 970-974.

Wilson, P.A. \& RoberTs, H.H. (1992) Carbonate-periplatform sedimentation by density flows: a mechanism for rapid off-bank and vertical transport of shallow-water fines. Geology, 20, 713-716.

Wilson, P.A. \& RoberTs, H.H. (1995) Density cascading; off-shelf sediment transport, evidence and implications, Bahama Banks. Journal of Sedimentary Research, 65, 4556.

\section{FIGURE CAPTIONS}

Figure 1: Regional map of the Bahamas, showing the bathymetry of the study area on the northwestern carbonate slope of the Great Bahama Bank. GBB (Great Bahama Bank), LBB (Little Bahama Bank), TOTO (Tongue of The Ocean). The trajectories of the main oceanic currents in the Bahamian Archipelago are represented by white dashed arrows, and locations of the contourite drifts along in the Florida Straits are marked by grey zones (from Bergman 2005).

Figure 2: Bathymetrical map of the study area showing the location of the Carambar cruise (Mulder et al., 2012) multichannel seismic reflection lines. Solid black lines mark the locations of seismic lines shown in subsequent figures. Note the location of wells used in the stratigraphic and sedimentological correlations for this study. Ocean Drilling Program (ODP) wells 626 (Austin et al., 1986), 1003-1004-1005-1006-1007 (Eberli et al., 1997a) are located on the slope and in the basin, whereas wells Clino and Unda of the Bahamas Drilling Project (Ginsburg, 2001) and the exploration well Great Isaac-1 are located on the platform.

Figure 3: A) Connection between the high-resolution seismic line of the Carambar cruise (Mulder et al., 2012) and the Western Geophysical Line (Eberli \& Ginsburg, 1987) showing a NE-SW transect evolution from the GBB platform to the adjacent basin. B) Interpretation of the seismic profile and well correlation of wells Unda, Clino drilled on the platform and 1005, 1004, 1003, 1007 and 1006 wells, order from proximal to distal. The seismic sequence boundaries defined in the subsurface of the platform by Eberli et al. (1997a) were extended into the basin, and depositional bodies are interpreted.

Figure 4: Well-to-seismic tie for establishment of a chronostratigraphy. Age, biostratigraphy, sedimentation rates, lithology, density and $\mathrm{Vp} \log$ data and time-depth law are from ODP 
well 1007 (Eberli et al., 1997). The seismic line is from the Carambar cruise (Mulder et al., 2012).

Figure 5: A) Uninterpreted seismic line showing the position of ODP wells used to the sedimentological calibration of seismic facies. B) Correlation of 1005-1004-1003-1007 and 1006 ODP wells from the upper slope to the basin. The stratigraphy of the wells is dominated by resedimented carbonates on the slope and contourite drift deposits in the basin. Core and stratigraphic information were taken and synthesis from reports of ODP Leg 166 (Eberli et al., 1997) and from Anselmetti et al., (2000).

Figure 6: A) Uninterpreted and B) interpreted N-S-oriented seismic profile across the basin (see Fig. 2 for location) showing the different seismic units through the Neogene strata. The ODP well 626 illustrates correlations between lithologic and seismic facies.

Figure 7: A) Uninterpreted and B) interpreted E-W-oriented seismic profile (see Fig. 2 for location) illustrating the dip geometries and the termination relationships of seismic facies in a basinward direction.

Figure 8: A) Uninterpreted and B) interpreted N-S-oriented seismic profile along the toe-ofslope (see Fig. 2 for location) showing the different seismic units through the Neogene strata. Figure 9: A) Uninterpreted and B) interpreted E-W-oriented seismic profile (see Fig. 2 for location) illustrating the dip geometries and the termination relationships of seismic facies in a basinward direction.

Figure 10: A) Uninterpreted and B) interpreted N-S-oriented seismic profile along the slope (see Fig. 2 for location) showing the different seismic units through the Neogene strata.

Figure 11: Isochron maps of the eight seismic stratigraphic surfaces (A: Late Oligocene; B: Aquitanian; C: Langhien; D: Serravallian; E: Messinian; F: Early Pliocene; G: Late Pliocene; $\mathrm{H}$ : Pleistocene) previously described showing the paleo-reconstruction of the study area since the Late Oligocene. The maps also illustrate the platform progradation through the Neogene. White areas correspond to seismic data gaps. Yellow dashes represent the basinward limit of the slope apron, orange continuous arrows show the onlapping contourite drift; and black arrows indicate the emplacement and direction of the contour current. Paleogeographic evolution of the GBB platform provides from Eberli and Ginsburg (1987, 1989).

Figure 12: Isochore maps of the eight depositional described periods (A: Late Oligocene to Aquitanian; B: Aquitanian to Langhian; C: Langhien to Serravalien; D: Serravallian to Messinian; E: Messinian to early Pliocene; F: Early to late Pliocene; G: Late PliocenePleistocene; H: Pleistocene to present-day) documenting the evolution of depositional units and their associated characteristic sedimentologic facies through time. The thickness is given 
in milliseconds two-way travel time, which is converted to approximate thickness in meters by using the displayed correlation, assuming an average velocity of $2600 \mathrm{~m} / \mathrm{s}$ (Anselmetti et al., 2000). Paleogeographic evolution of the GBB platform provides from Eberli and Ginsburg $(1987,1989)$.

Figure 13: Correlations between major gravity-flow deposits occurring along the northwestern GBB and regional tectonic, climatic, oceanic and biologic events during the Neogene and Quaternary. Global sea-level curves in light blue and green respectively provide from Haq (1988) and Miller et al. (2005). $\delta^{18} \mathrm{O}$ curve (red) provides from Cramer et al. (2009). Planktonic foraminifers zones provide from Blow (1979), Berggren and Miller (1988) and Berggren et al. (1995). Calcareous nannofossils zones provide from Lourens et al. (GTS 2004 tables).

Figure 14: Conceptual model illustrating the evolution of the northwestern platform- tobasin Great Bahama Bank through the Neogene to recent time interval. A: Miocene slope apron with megabreccia. B: Miocene slope apron dominated by muddy calciturbidite deposition. C: Lower Pliocene: generalized flooding of the platform and stop of the slope apron evolution. D: Upper Pliocene: base-of-slope apron configuration characterized by a growth pulse of the contourite drift in the basin and massive debrites by-passed into canyons and deposited into the moat. E: Pleistocene: recovery of a slope apron system.

Table 1: Age correlation of seismic horizons.

Table 2: Summary of properties and interpretation of the seismic facies encountered in this study. 


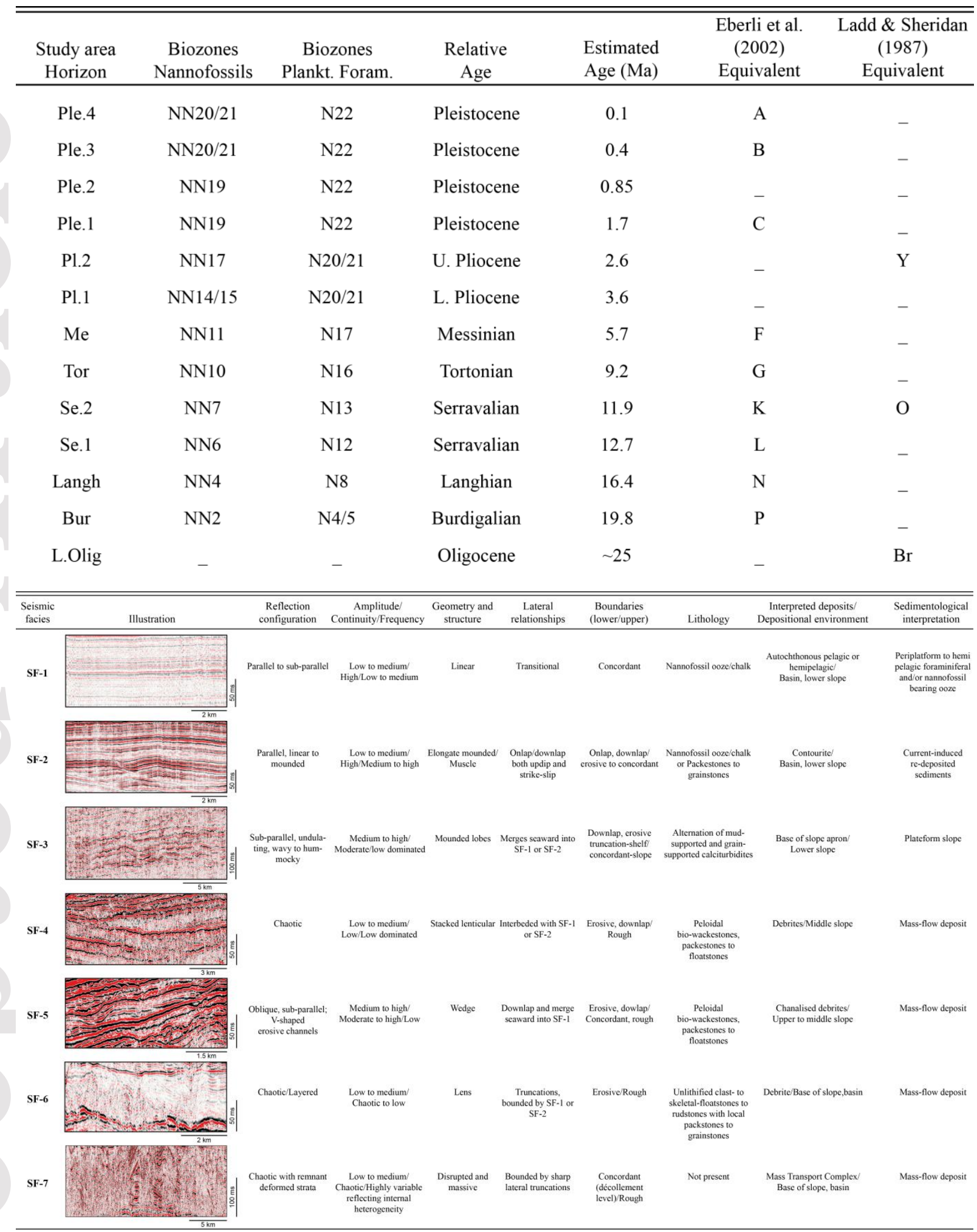




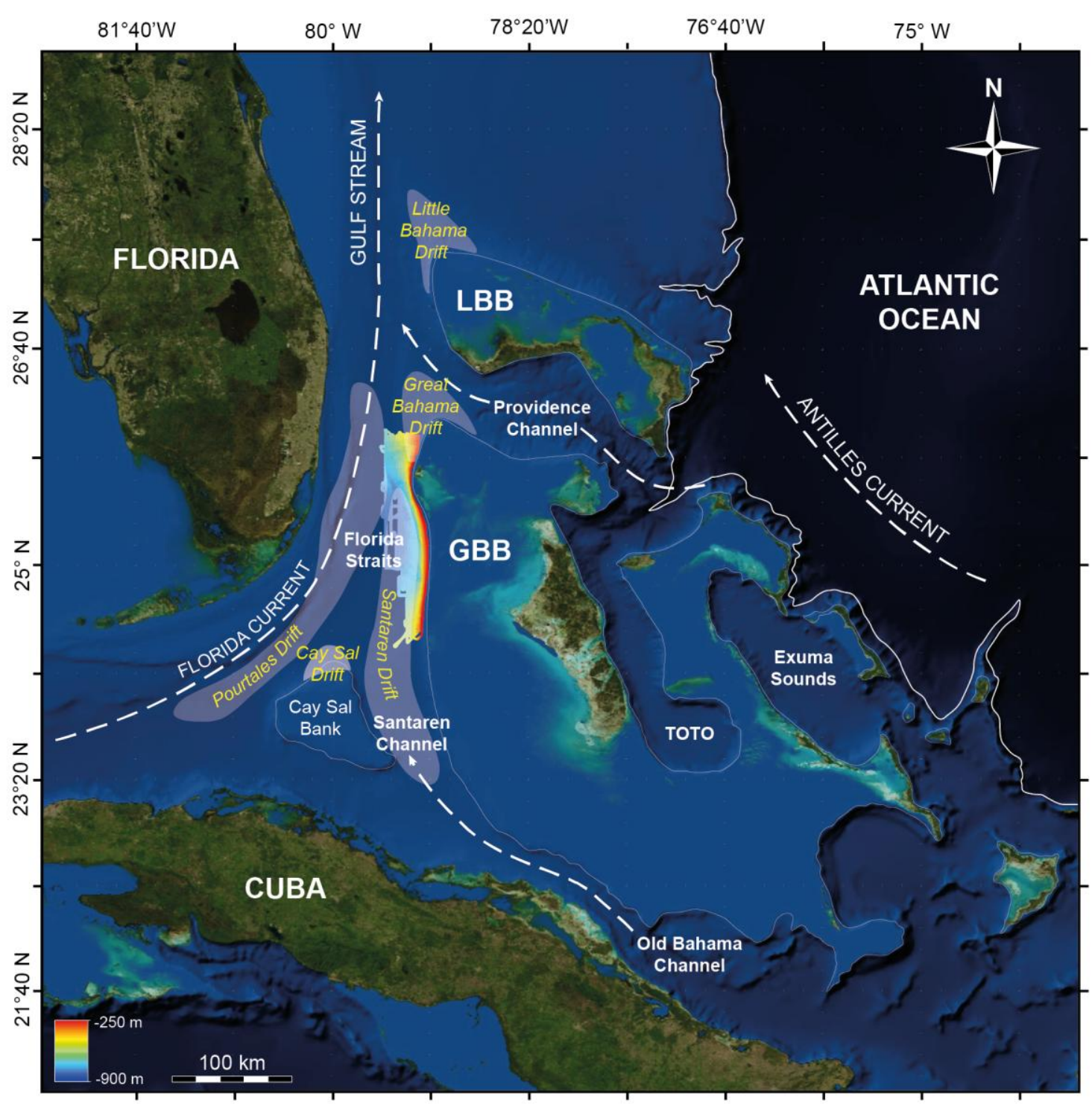

This article is protected by copyright. All rights reserved. 


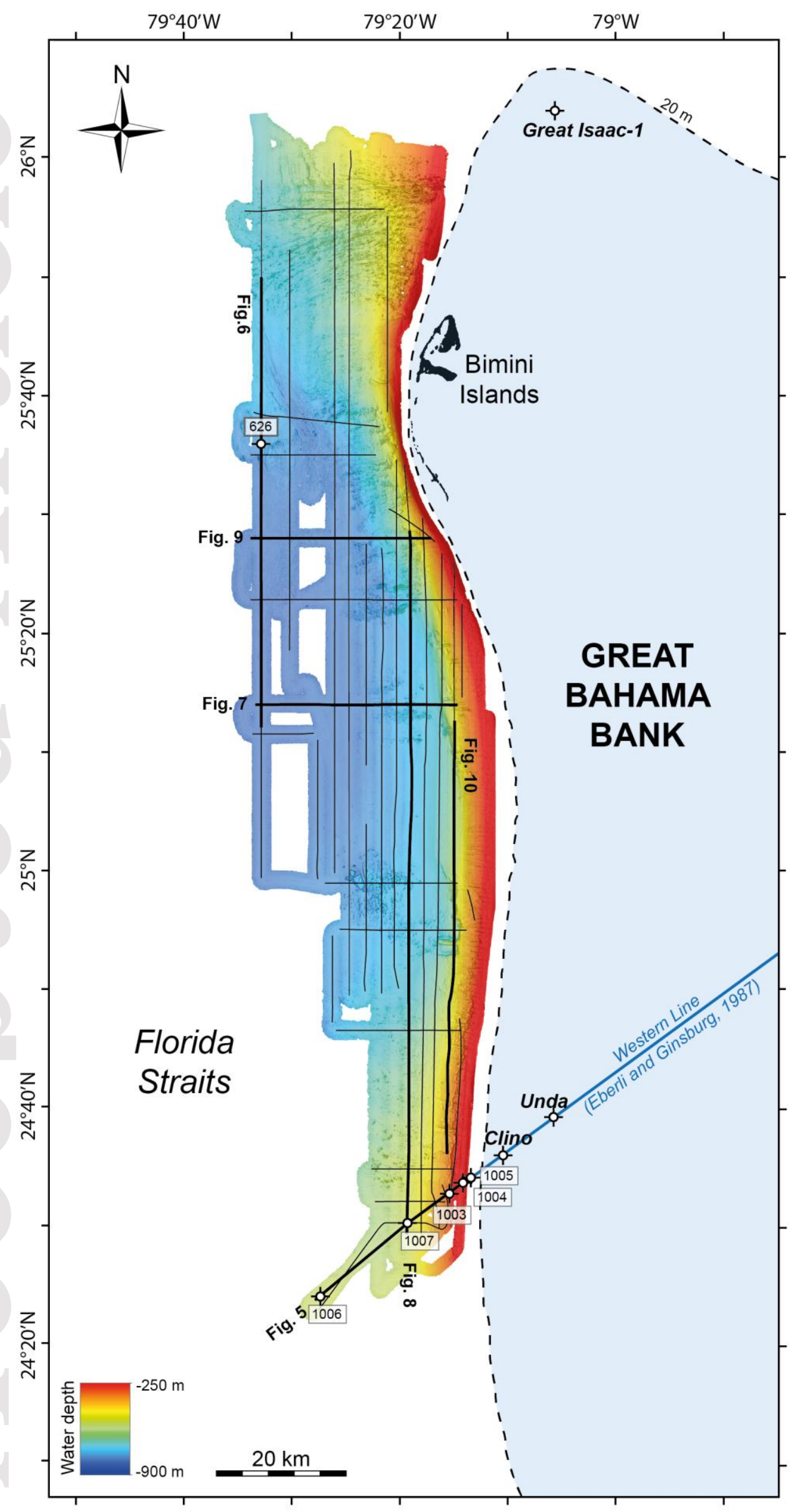

This article is protected by copyright. All rights reserved. 


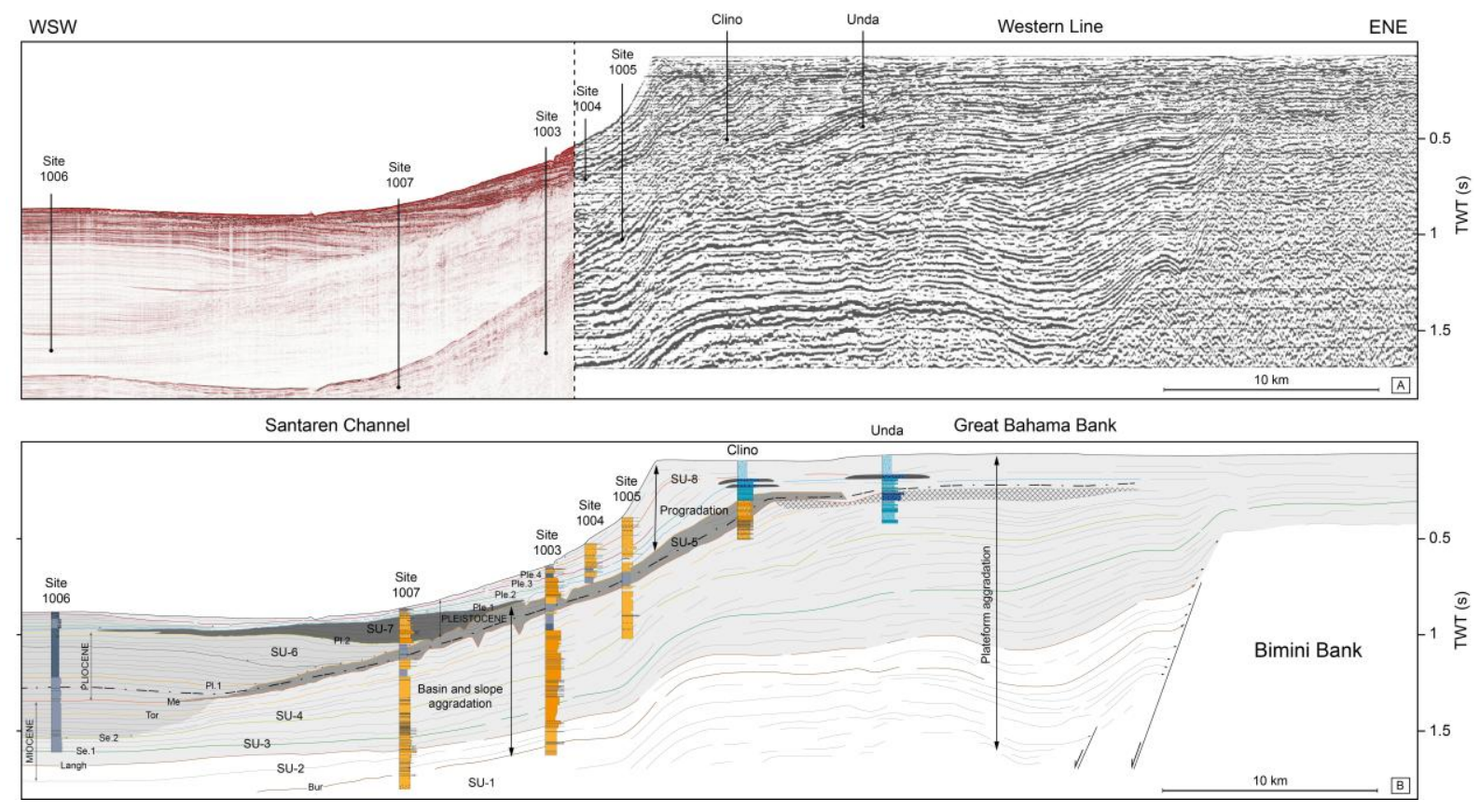

This article is protected by copyright. All rights reserved. 


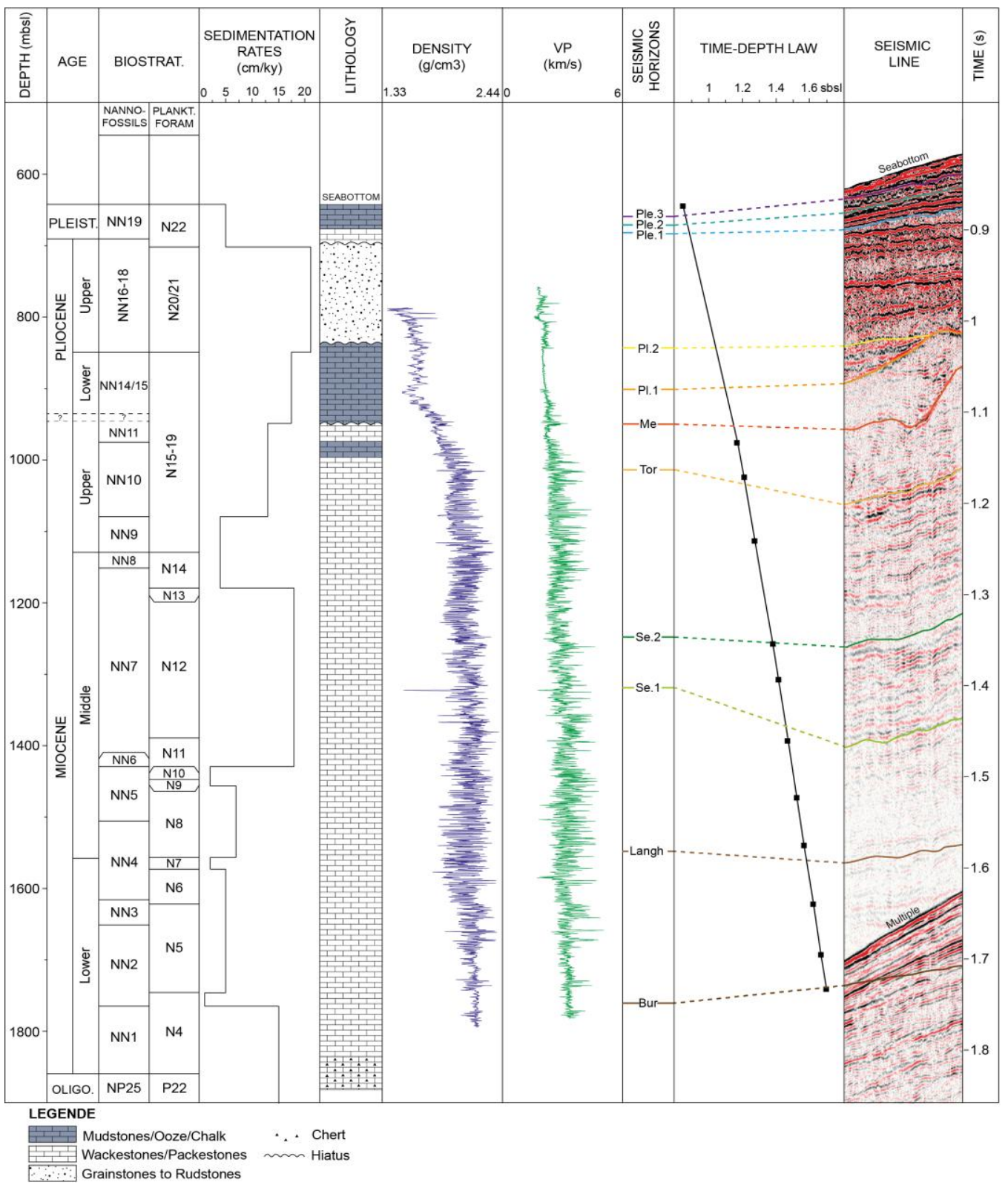

This article is protected by copyright. All rights reserved. 

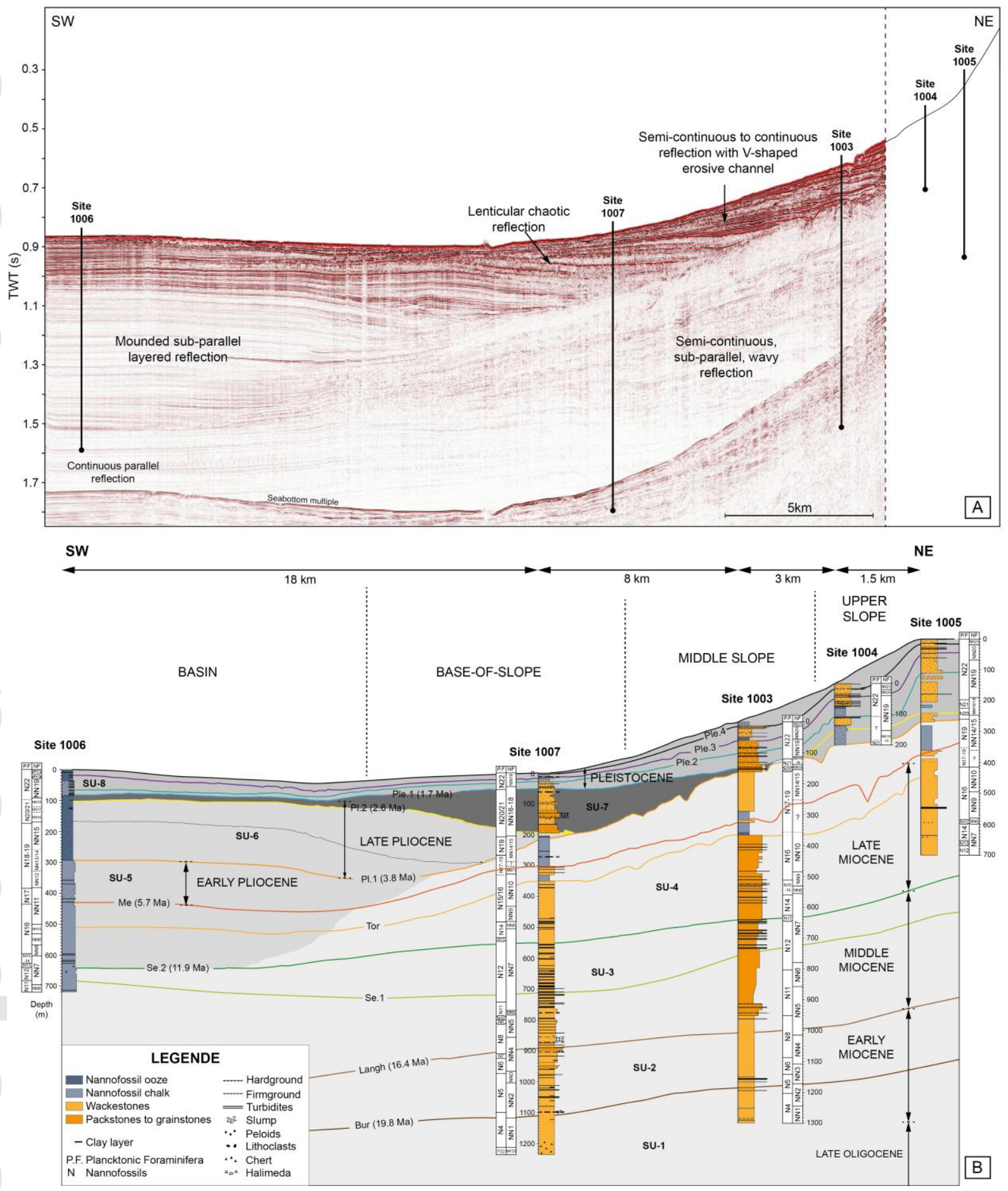

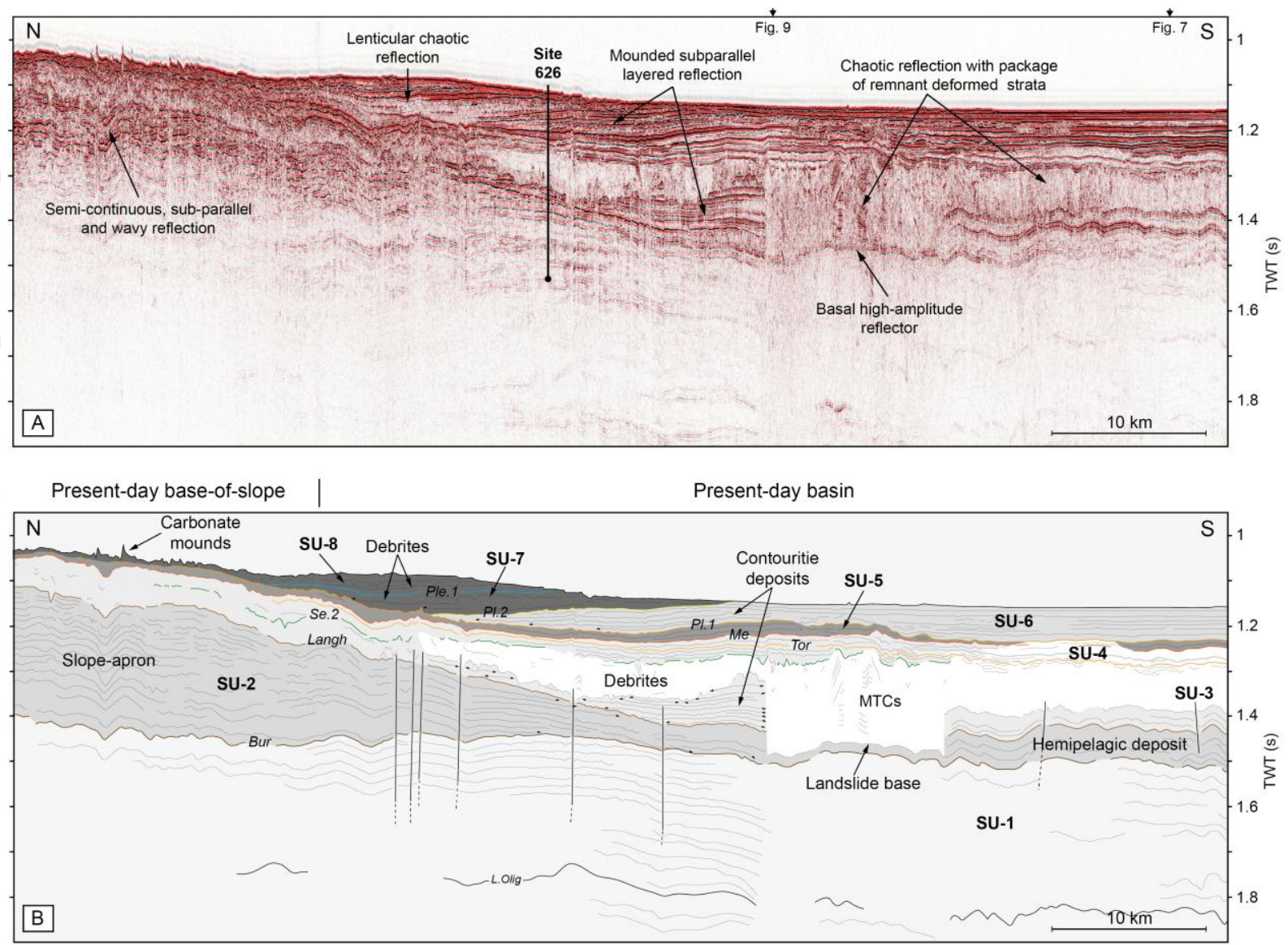

This article is protected by copyright. All rights reserved. 


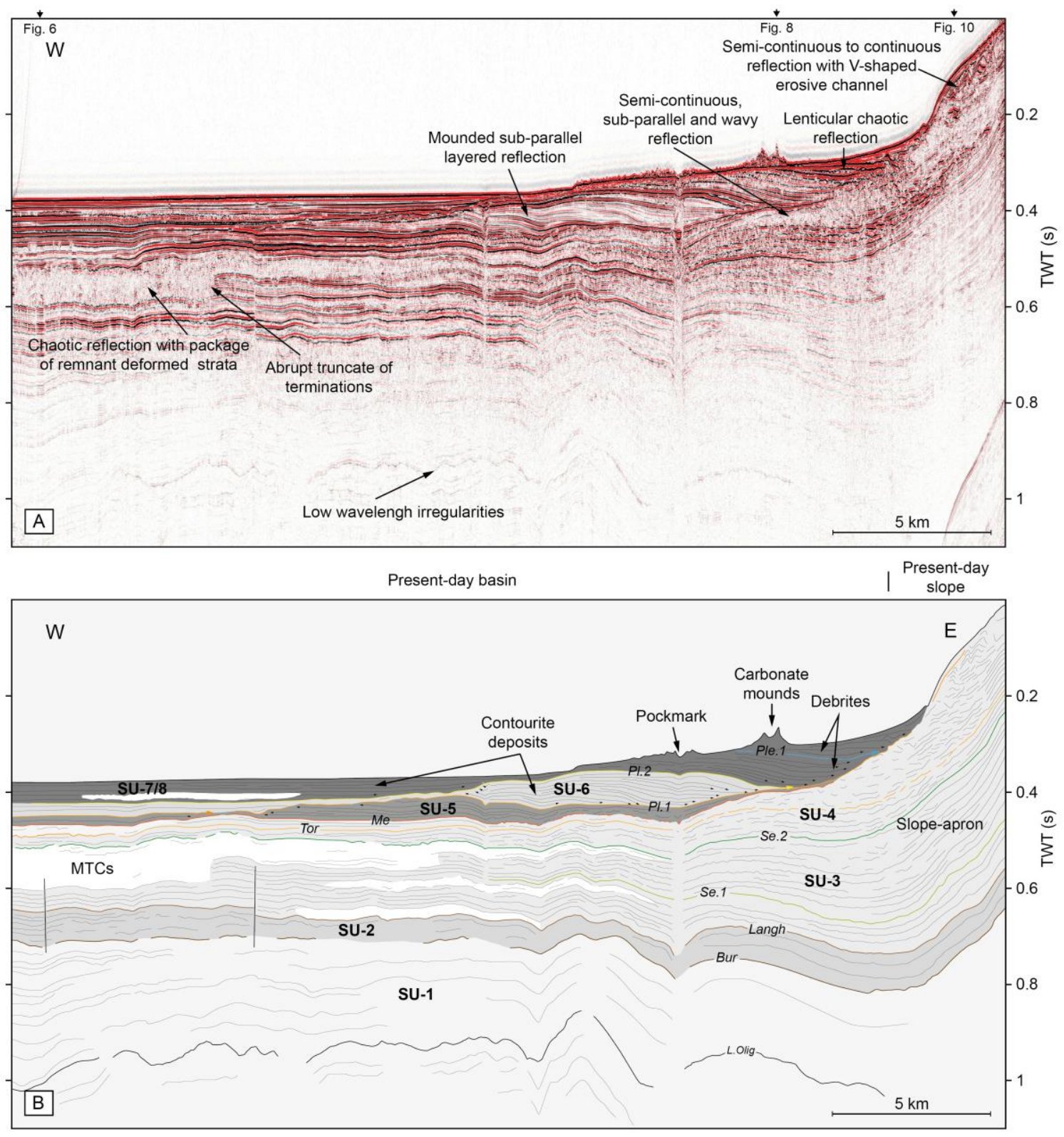

This article is protected by copyright. All rights reserved. 

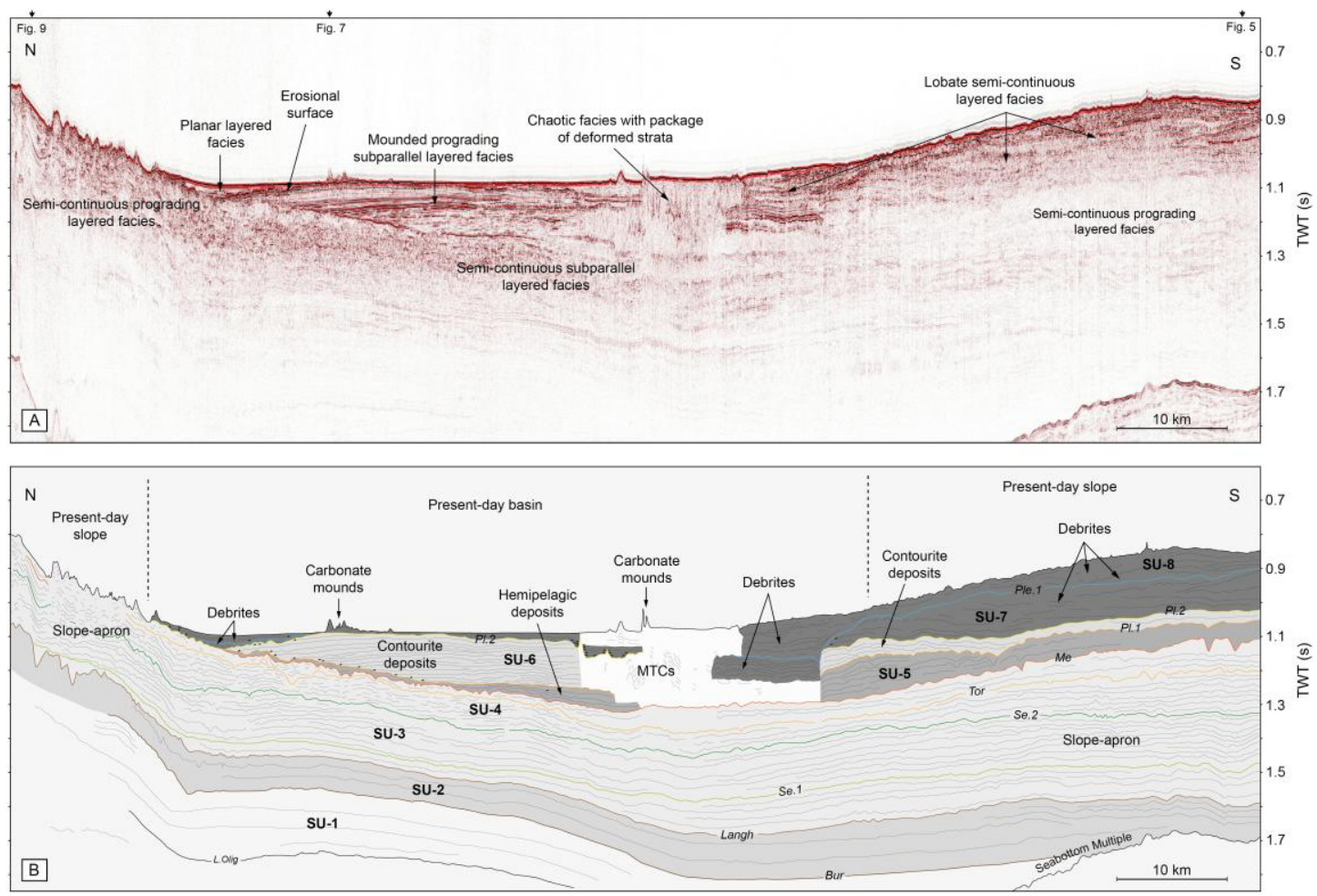

This article is protected by copyright. All rights reserved. 

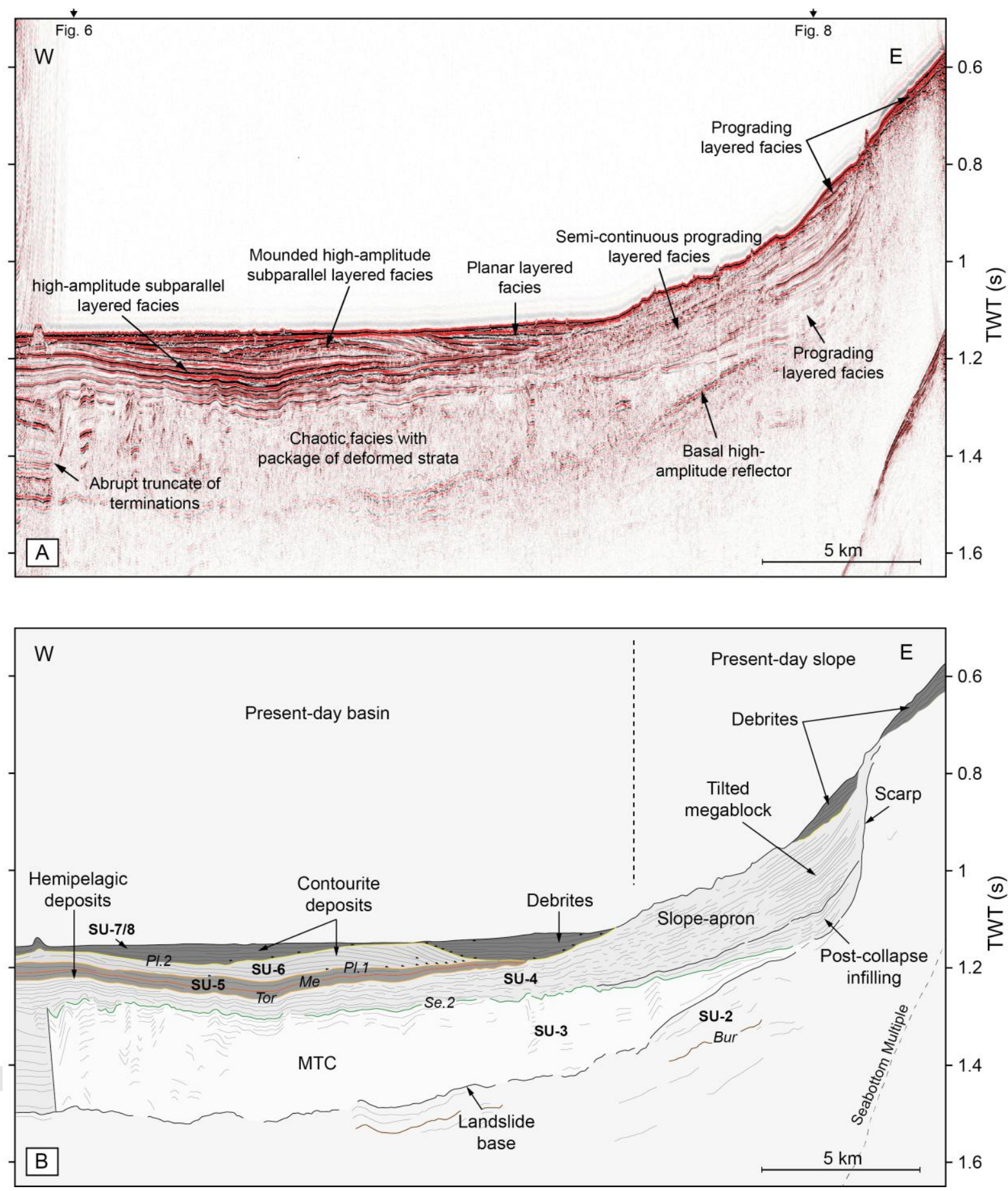

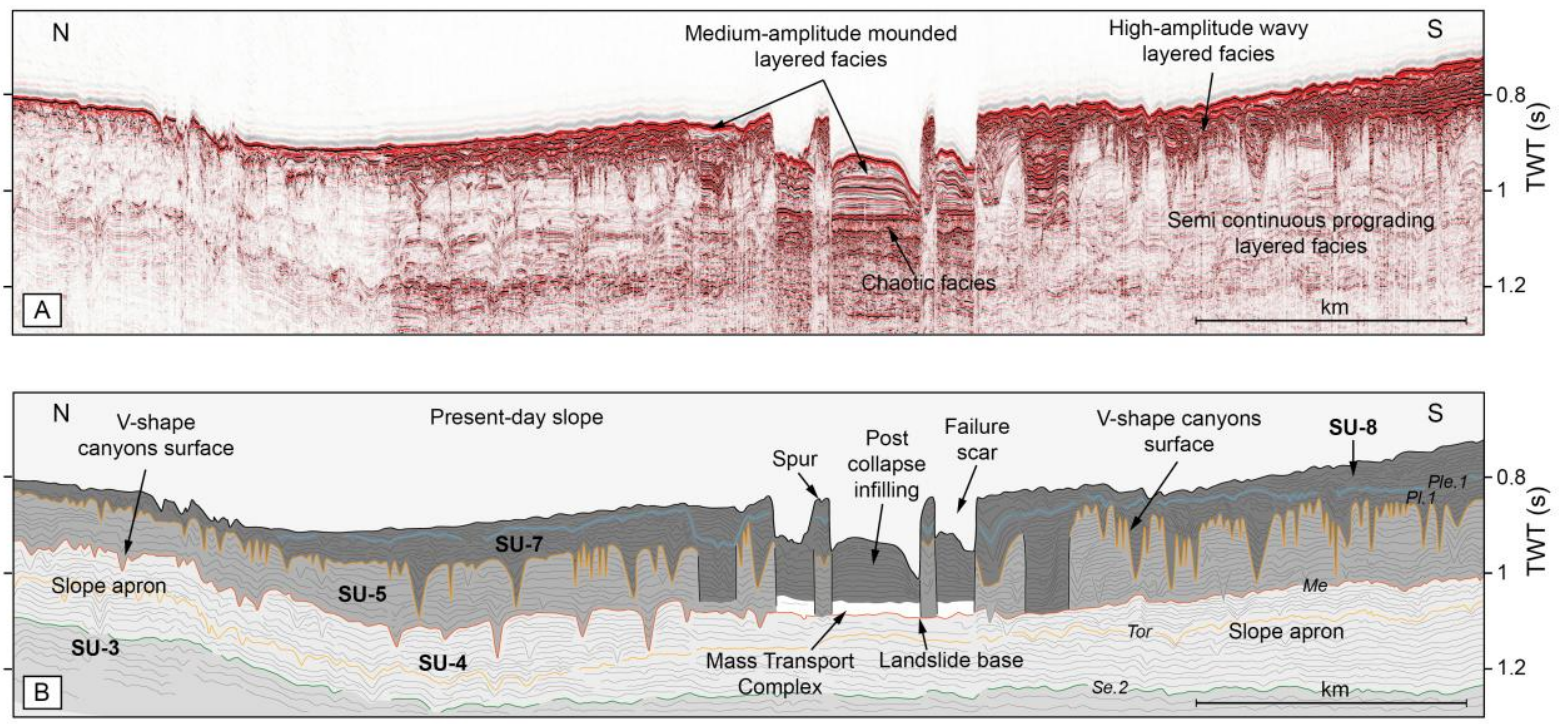

This article is protected by copyright. All rights reserved. 

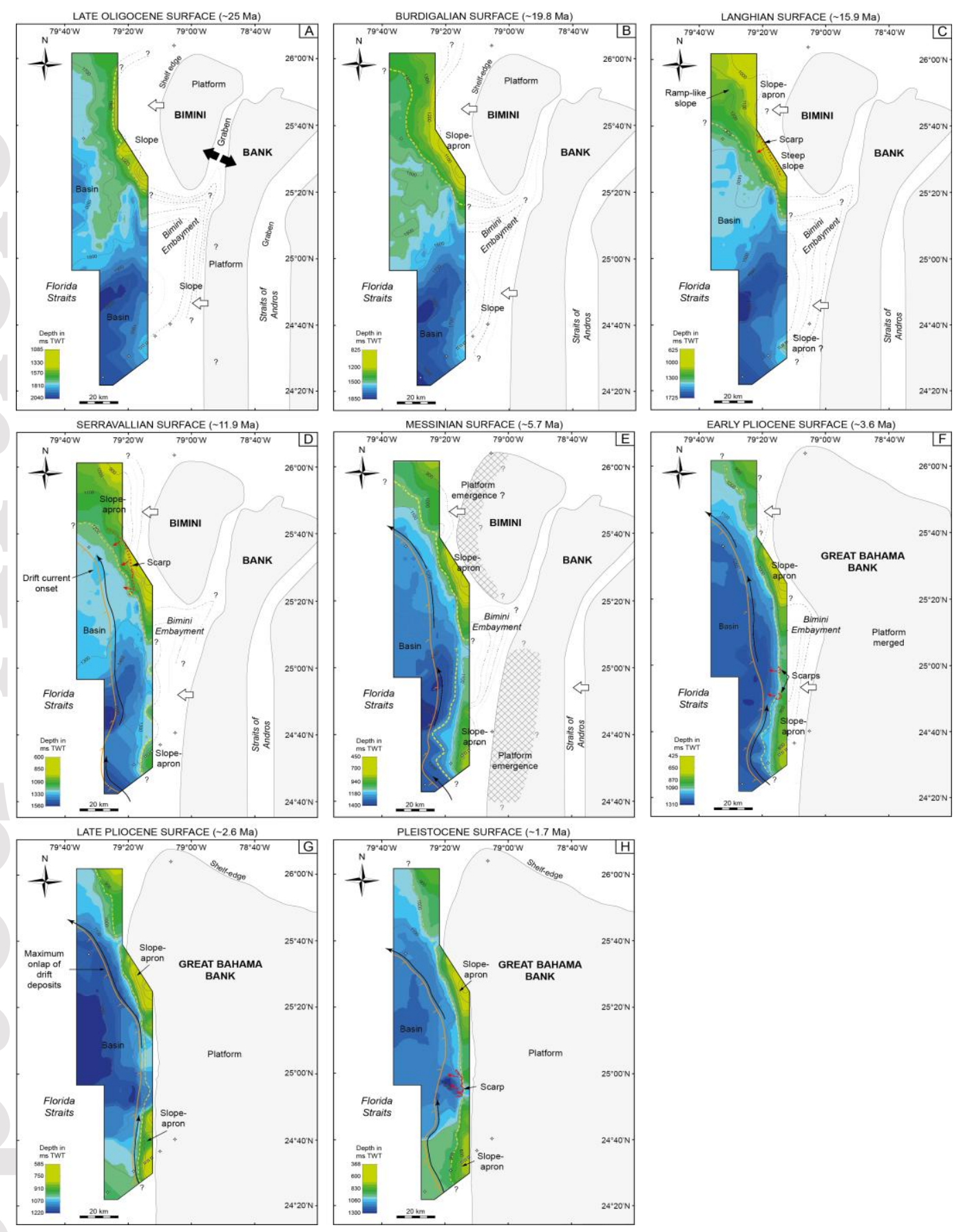

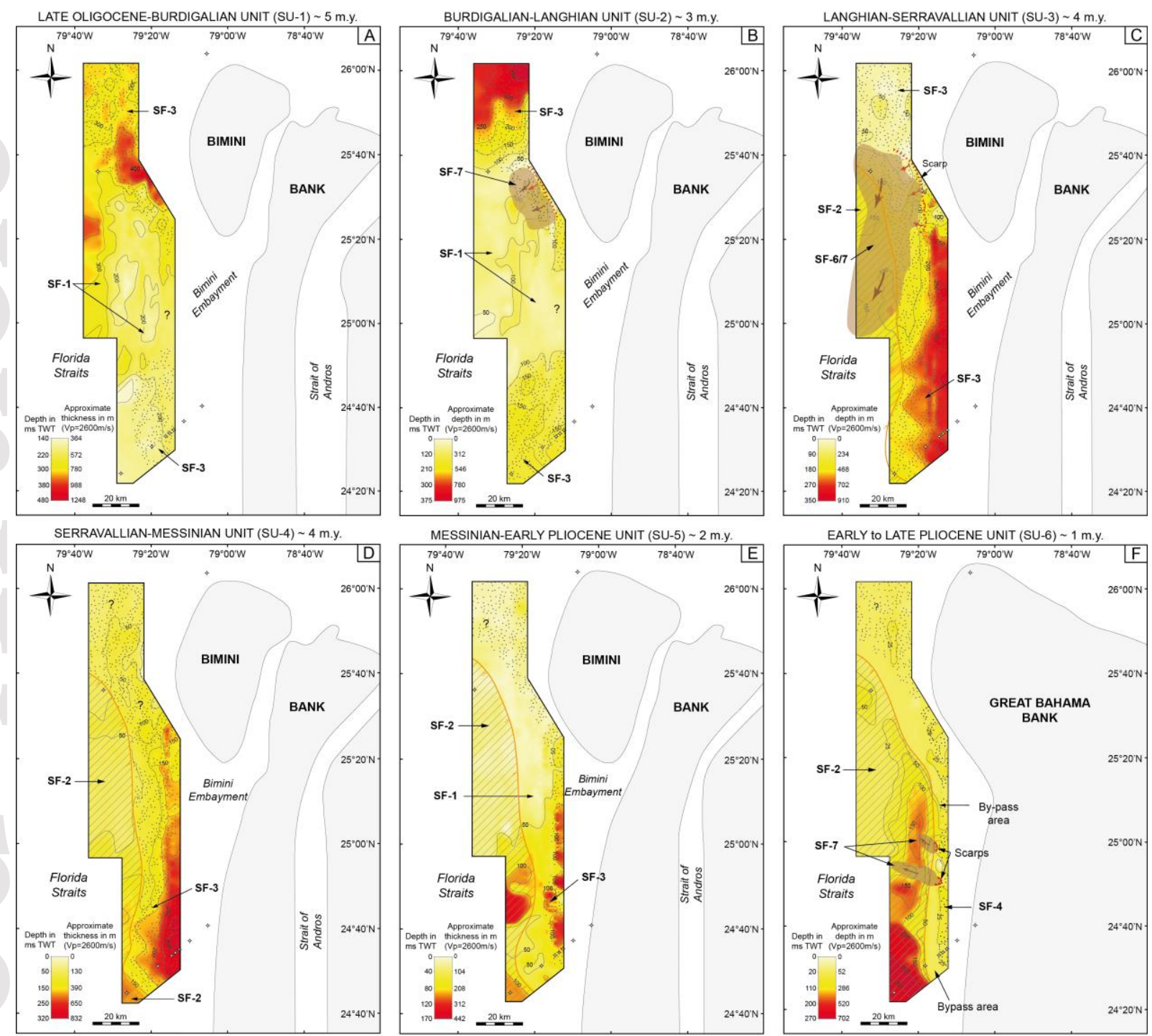

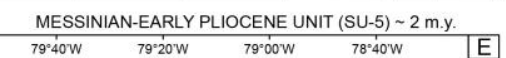
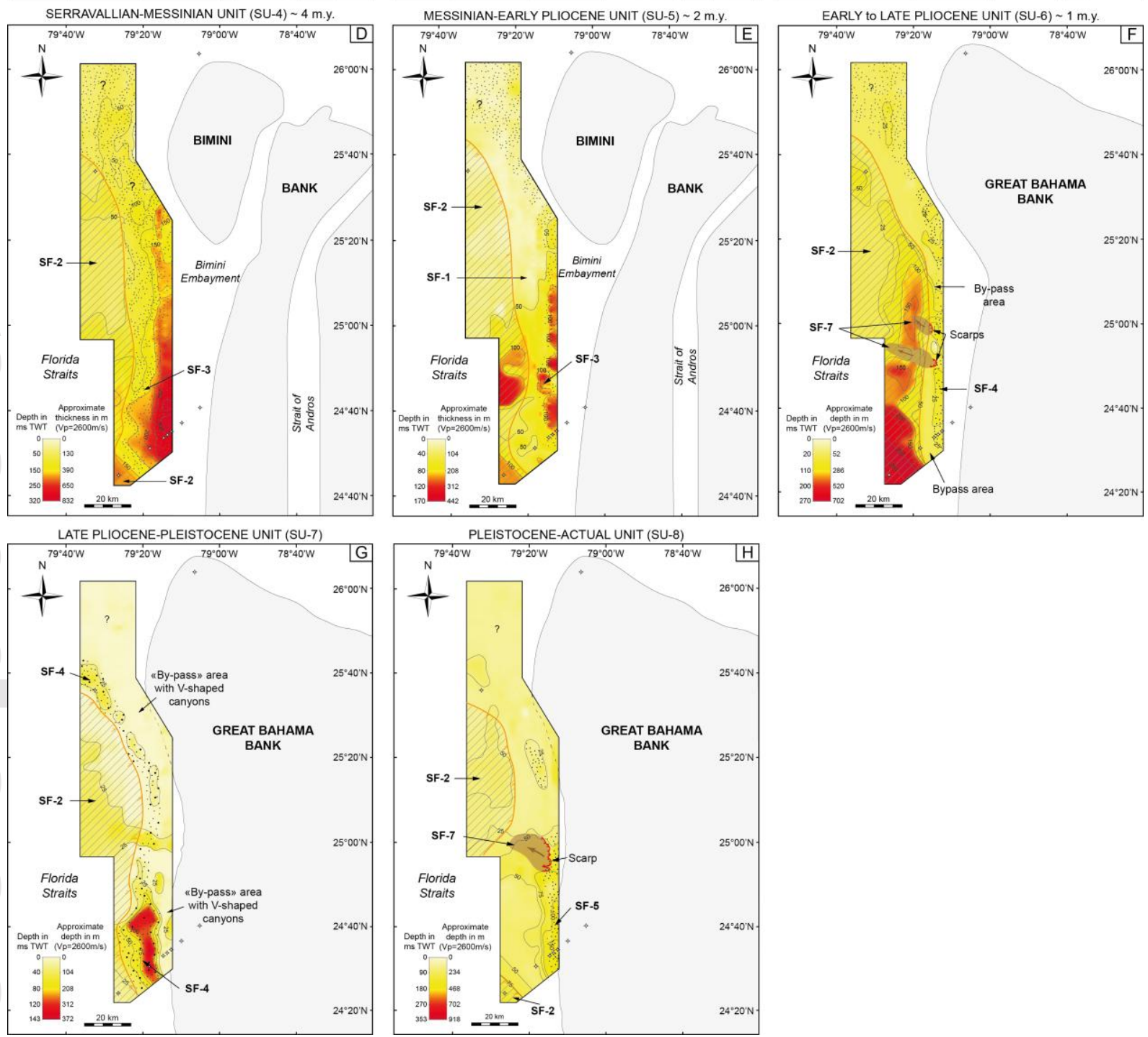


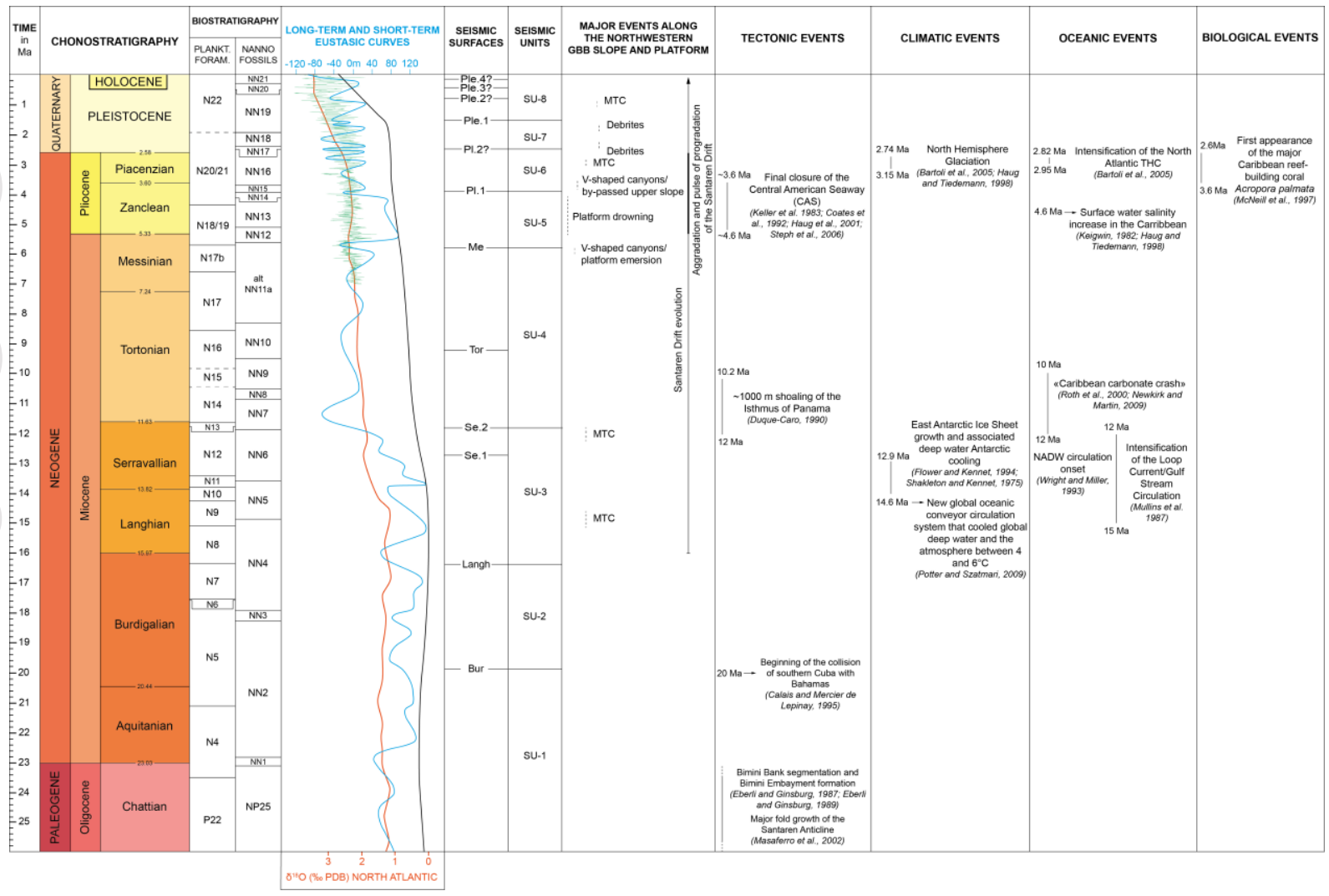

This article is protected by copyright. All rights reserved. 


\section{PLEISTOCENE}

W

(E)

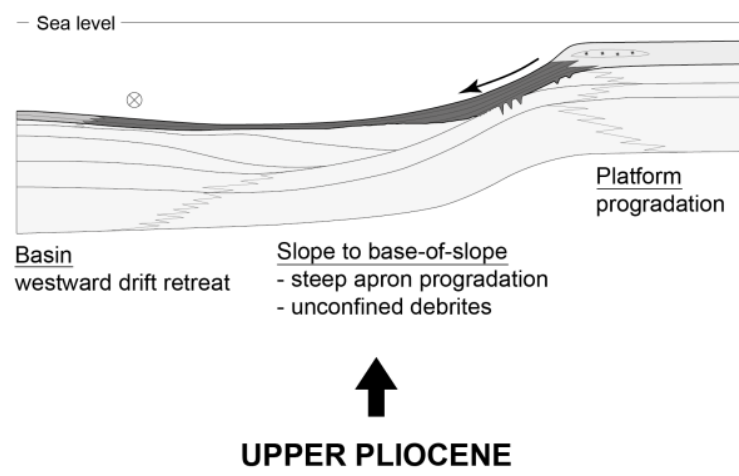

W

E

(D)

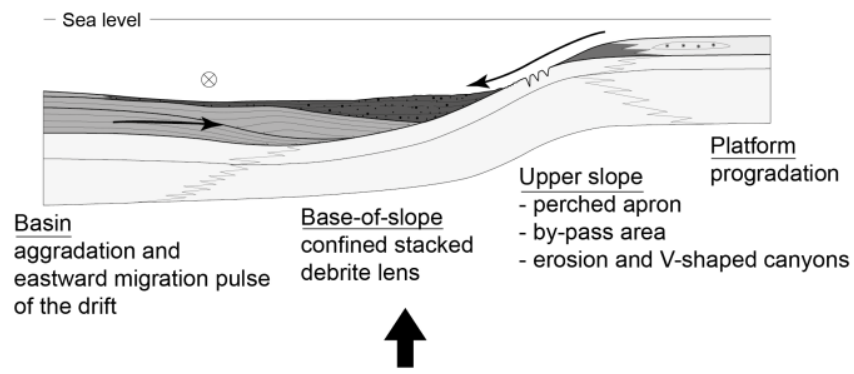

\section{LOWER PLIOCENE}

w

E

Sea level rise

(C)

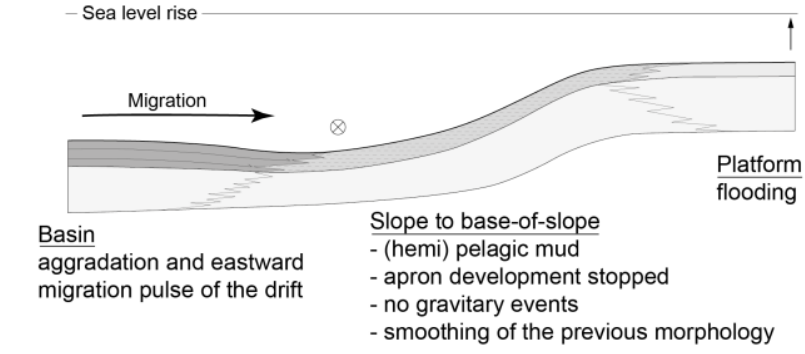

$>$ Calciturbidites

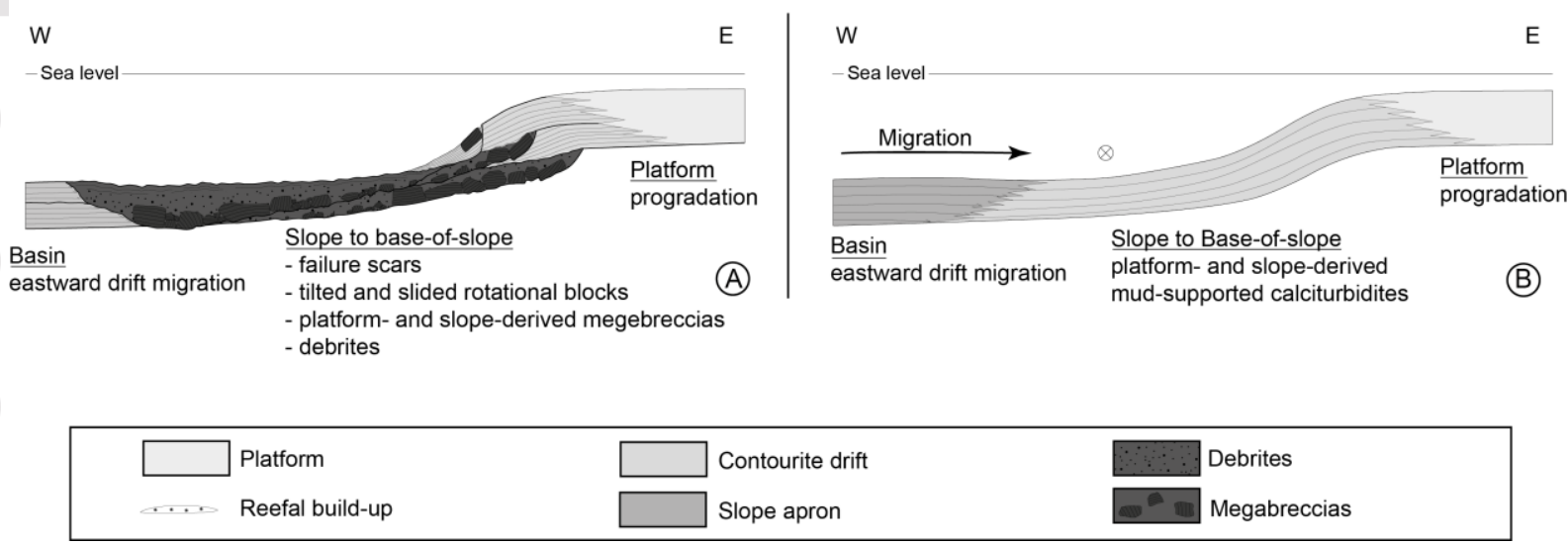

This article is protected by copyright. All rights reserved. 